\title{
All-inclusive descriptions of new freshwater snail taxa of the hyperdiverse family Tateidae (Gastropoda, Caenogastropoda) from the South Island of New Zealand
}

\author{
Gerlien VERHAEGEN ${ }^{1} \&$ Martin HAASE, ${ }^{2, *}$ \\ ${ }^{1,2} \mathrm{AG}$ Vogelwarte, Zoological Institute and Museum, University of Greifswald, \\ Soldmannstraße 23, Greifswald, Germany. \\ ${ }^{1}$ Present address: Japan Agency for Marine-Earth Science and Technology (JAMSTEC), \\ Institute for Extra-cutting-edge Science and Technology Avant-garde Research (X-star), \\ Advanced Science-Technology Research (ASTER) Program, 2-15, Natsushimacho, \\ Yokosuka, Kanagawa 237-0061, Japan. \\ *Corresponding author: martin.haase@uni-greifswald.de \\ ${ }^{1}$ Email: gerlienverhaegen@hotmail.com \\ ${ }^{1}$ urn:lsid:zoobank.org:author:218491F7-1BE3-438C-8CAE-F11733A06D5C \\ ${ }^{2}$ urn:1sid:zoobank.org:author:8CE4B347-14C5-464F-99C4-DE2263FC55D5
}

\begin{abstract}
Four new species and one new subspecies of tateid freshwater gastropods are described from the north of the South Island of New Zealand, Catapyrgus jami sp. nov., Opacuincola lisannea sp. nov., O. gretathunbergae sp. nov., O. mete kahurangi ssp. nov. and Obtusopyrgus farri sp. nov. The species are integratively defined based on a combination of shell morphological, anatomical and mitochondrial DNA data. Morphological and anatomical data were generated by morphometrics, scanning electron microscopy, as well as micro-computed tomography. The genetic data were basis of phylogenetic analyses and incorporated into the diagnoses. The new taxa occur in springs or spring-like habitats, i.e., shallow, slowflowing sections of small streams except for $O$. mete kahurangi subsp. nov., which was collected from rough rocks in a river, where the snails sat in small depressions. None of the species exceeded $2.75 \mathrm{~mm}$ in length. Opacuincola gretathunbergae sp. nov. and Obtusopyrgus farri sp. nov. are pigmented and true crenobionts, while $C$. jami sp. nov. and the sympatric Opacuincola lisannea sp. nov. have eyes of reduced size and lack epidermal pigment, hence, probably dwell in the transitional zone of epigean and groundwaters.
\end{abstract}

Keywords. Diagnostic molecular characters, DNA taxonomy, micro-computed tomography, phylogeny.

Verhaegen G. \& Haase M. 2021. All-inclusive descriptions of new freshwater snail taxa of the hyperdiverse family Tateidae (Gastropoda, Caenogastropoda) from the South Island of New Zealand. European Journal of Taxonomy 731: 71-96. https://doi.org/10.5852/ejt.2021.731.1205

\section{Introduction}

Tateidae is an extremely diverse family of minute aquatic gastropods occurring in Australasia from Sulawesi over New Guinea to Australia and Tasmania as well as on Pacific islands and island groups 
including, Lord Howe Island, New Caledonia, New Zealand, Vanuatu, Fiji and the Austral Islands. In South America, the family is represented by the genus Potamolithus Pilsbry, 1896 (Ponder 2019). The vast majority of the over 300 species lives in fresh water, only six dwell in brackish waters - one of them, the notorious Potamopyrgus antipodarum (Gray, 1843), which is native to New Zealand and has invaded Australia, Europe, North and South America as well as Japan, facultatively (Ponder 1988, 2019; Haase 2008; Alonso \& Castro-Díez 2012). The high diversity is linked to the high degree of endemicity with many species, notably the very small ones, occurring in very restricted ranges sometimes not exceeding a single valley (e.g., Ponder 1982; Haase \& Bouchet 1998; Haase 2008). In New Zealand, even entire lineages of genera have restricted ranges conserving historical biogeographic information extending back to the mid Miocene (Haase et al. 2007a).

Against this background, it is not surprising that unknown species are being discovered at a considerable rate, most of them in the past 30 years (Ponder 2019). This is also a consequence of the availability of molecular methods allowing the identification of cryptic species and genera among these small-sized animals (e.g., Haase 2008; Zielske \& Haase 2015). We have to stress, though, that DNA comparisons are not a cure-all as in particular young speciation events will not be reflected in mtDNA commonly used to delimitate species (for examples see, e.g., Haase 2008), which is why we advocate the integration of several approaches in taxonomy (Dayrat 2005; Haase et al. 2007b).

In the course of our fieldwork for Verhaegen et al. (2018b) on the ecomorphology of P. antipodarum, we discovered as by-catch four new species and one new subspecies which we describe here. We integrated morphometrics, anatomical dissections, scanning electron microscopy (SEM), micro-computed tomography $(\mu \mathrm{CT})$, as well as molecular phylogenetic analyses in order to define the new taxa. For the four new species, we also identified diagnostic molecular characters (Kühn \& Haase 2020).

\section{Material and Methods}

\section{Material}

Snails were collected at five localities (Fig. 1; mapped with QGIS ver. 2.18.24 using the vector maps publicly available from Natural Earth (https://www.naturalearthdata.com/)) in the north of New Zealand's South Island in February and March 2016. They were fixed on the spot in 70\% ethanol, transferred to propylene glycol prior to transportation to Germany, and, upon arrival, stored in $96 \%$ ethanol at $4^{\circ} \mathrm{C}$. Additional material, all paratypes of the following species, was provided by the National Museum of New Zealand Te Papa Tongarewa (NMNZ) for morphological comparison: Catapyrgus fraterculus Haase, 2008 (NMNZ.M.174158; n=3), C. matapango Haase, 2008 (NMNZ.M.174169; 11), C. spelaeus Climo, 1974 (NMNZ.M.032461; 10), Obtusopyrgus alpinus Haase, 2008 (NMNZ.M.174189; 11), Opacuincola mete Haase, 2008 (NMNZ.M.174134; 2), Op. ngatapuna Haase, 2008 (NMNZ.M.174122; 2), Op. takakaensis Haase, 2008 (NMNZ.M.022245; 20) and Op. terraelapsus Haase, 2008 (NMNZ.M.158196; 16). These taxa were selected because of their high similarity, relatedness, and geographic proximity to the new species. We did not use the measurements given in Haase (2008), because here GV did all the measurements and because the measuring methods differed compromising exact comparability (Schilthuizen \& Haase 2010).

\section{Microscopy}

Up to 20 adult shells defined by a continuous, thickened apertural lip (e.g., Verhaegen et al. 2018a) were measured from photographs taken with a Zeiss SteREO Discovery ver. 20 dissecting microscope equipped with a Plan Apo S $0.63 \times$ objective and a Zeiss Axio Cam MR3 using the program AxioVision 40 ver. 4.8. (Zeiss). The dimensions shell height, shell width, width of body whorl, aperture height and aperture width were measured parallel or perpendicular to the coiling axis. In addition, the number of whorls was counted to the nearest eighth (Kerney \& Cameron 1979). Statistical comparisons including 
a principal component analysis (PCA) and univariate tests were conducted in PAST ver. 4.01 (Hammer et al. 2001).

\section{Micro-computed tomography}

The anatomy of one female and one male of each new (sub)species was studied using micro-computed tomography at the Imaging Centre of the University of Greifswald. Prior to scanning, shells were dissolved in 0.5M EDTA ( $\mathrm{pH}=7.5$ ) for two days, post-fixed in paraformaldehyde for another two days, then rinsed in distilled water for 10 minutes and finally transferred to a $0.3 \%$ solution of phosphotungstic acid in $96 \%$ ethanol for further two days to enhance the contrast of tissues. Mounted in a plastic pipette tip filled with $99 \%$ ethanol and sealed with hot glue, snails were scanned with an Xradia Micro XCT$200 \mu \mathrm{CT}$ (Carl Zeiss X-ray Microscopy Inc.) at a voltage of $40 \mathrm{kV}$, a power of $8 \mathrm{~W}$, and ten times magnification. The resulting image stacks were analyzed and the reproductive organs reconstructed in three dimensions (3D) using AMIRA ver. 6.0.1 (FEI, Visualization Science Group).

\section{Scanning electron microscopy and dissections}

Shells, radulae, opercula and penes were investigated by scanning electron microscopy. Two shells of each species were cleaned in ca $2.5 \%$ sodium hypochlorite. For the remaining characters, shells had to be dissolved in $1 \mathrm{M}$ hydrochloric acid. For radulae and opercula the soft bodies of up to three specimens were dissolved in sodium hypochlorite. If available, penes of two males were dissected free and dried in hexamethyldisilazane (Nation 1983) after dehydration in ethanol and transfer to $100 \%$ acetone.

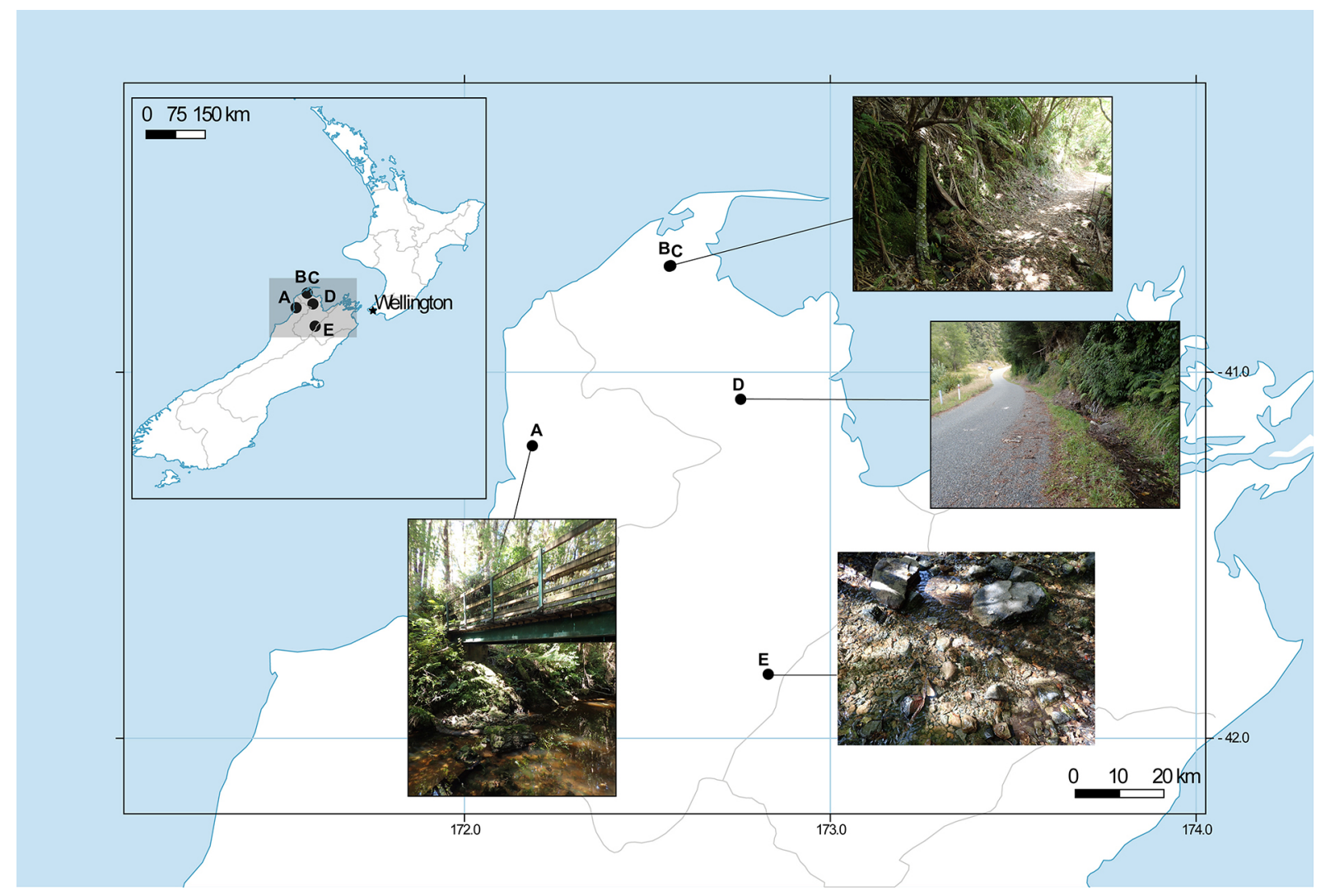

Fig. 1. Localities. A. Type locality of Opacuincola mete kahurangi subsp. nov. B. Type locality (photograph) of Catapyrgus jami sp. nov. and Op. lisannea sp. nov. C. Northern locality of Op. lisannea sp. nov. D. Type locality of Op. gretathunbergae sp. nov. E. Type locality of Obtusopyrgus farri sp. nov. For details see descriptions in text. 
Specimens were mounted with carbon tabs, coated with palladium/platinum with a Fisons Polaron SC7640 sputter coater and then photographed in a Zeiss EVO LS10 SEM, again at the Imaging Centre of the University of Greifswald. In the specimens dissected for SEM, we also studied the remaining anatomy including the genitalia. The total numbers of investigated genitalia, including in most cases one $\mu \mathrm{CT}$-scanned specimen, are given in the species descriptions. Only data of mature individuals are reported.

\section{Molecular analyses}

DNA was extracted from three specimens per sample with the E.Z.N.A® Mollusc DNA Kit (Omega Bio-Tek Inc.) by crushing the entire snail and following the manufacturer's protocol. We amplified two mitochondrial fragments: $658 \mathrm{bp}$ of the cytochrome c oxidase subunit I gene (COI) using Folmer et al. (1994) primers LCO1490 and H1298, the latter modified at position 12 (A instead of G) by Zielske et al. (2011) and ca 500 bp of the 16S ribosomal RNA gene (16S) with primers 16Sar-L and 16Sbr-H (Palumbi et al. 1991). Polymerase chain reactions (PCR) were performed in a total volume of $11 \mu \mathrm{L}$ and consisted for COI of $1 \mu \mathrm{L}$ of DNA solution $(\sim 20 \mathrm{ng}), 4.10 \mu \mathrm{L}$ of water, $5 \mu \mathrm{L}$ of HS MyTaqTM RedMix (Bioline), $0.40 \mu \mathrm{L}$ of $1 \%$ BSA and $0.25 \mu \mathrm{L}$ of each primer (from a 10 pmol stock solution). For $16 \mathrm{~S}$, the mix was similar except that we added $4.60 \mu \mathrm{L}$ of water and $0.20 \mu \mathrm{L}$ of each primer. The temperature profile for COI was $1 \mathrm{~min}$ of initial denaturation at $95^{\circ} \mathrm{C}$ followed by 40 cycles comprising $20 \mathrm{~s}$ denaturation at $95^{\circ} \mathrm{C}, 30 \mathrm{~s}$ annealing at $48^{\circ} \mathrm{C}$, and $1 \mathrm{~min}$ extension at $72^{\circ} \mathrm{C}$, and a final extension at $72^{\circ} \mathrm{C}$ for $5 \mathrm{~min}$. For $16 \mathrm{~S}$ we had a touch-down protocol with $1 \mathrm{~min}$ initial denaturation at $95^{\circ} \mathrm{C}, 10$ cycles with $20 \mathrm{~s}$ denaturation at $95^{\circ} \mathrm{C}, 20 \mathrm{~s}$ annealing starting at $60^{\circ} \mathrm{C}$ and dropping by 1 degree in each cycle to $51^{\circ} \mathrm{C}$, and 1 min extension at $72^{\circ} \mathrm{C}$, followed by further 25 cycles consisting of $20 \mathrm{~s}$ denaturation at $95^{\circ} \mathrm{C}, 20 \mathrm{~s}$ of annealing at $51^{\circ} \mathrm{C}$, and $1 \mathrm{~min}$ extension at $72^{\circ} \mathrm{C}$, and the $5 \mathrm{~min}$ final extension at $72^{\circ} \mathrm{C}$. PCR products were visualised on a $1 \%$ agarose gel and purified with an exonuclease I and shrimp alkaline phosphatase mix. Cycle sequencing was conducted using the BigDye ${ }^{\mathrm{TM}}$ Terminator ver. 3.1 Cycle Sequencing Kit (Applied Biosystems) with 50\% replaced by halfBD (Sigma-Aldrich) and the PCR primers. The cycle sequencing products were cleaned with magnetic beads using the HighPrepTM DTR Dye Terminator Removal Clean Up (MagBio Genomics) and then sequenced on an ABI 3130xl Genetic Analyser (Applied Biosystems).

Sequences were edited in Geneious ver. 10.2.3 (https://www.geneious.com) and BioEdit 7.0.5.3 (Hall 1999) and aligned with the data of Haase (2008) using MAFFT with the default settings (Katoh et al. 2019). The alignment was finally trimmed to $644 \mathrm{bp}$ for COI and $482 \mathrm{bp}$ for $16 \mathrm{~S}$. An exhaustive search with PartitionFinder ver. 2.1.1 (Lanfear et al. 2017) suggested a total of four partitions, one per COI codon position and one for $16 \mathrm{~S}$. The best fitting substitution models based on the Bayesian information criterion were $\mathrm{TRN}+\mathrm{I}+\mathrm{G}, \mathrm{HKY}+\mathrm{I}$ and $\mathrm{GTR}+\mathrm{G}$ for $1^{\text {st }}$ to $3^{\text {rd }}$ codon positions, respectively, and $\mathrm{TIM}+\mathrm{I}+\mathrm{G}$ for $16 \mathrm{~S}$. Based on this scheme, we conducted a maximum likelihood (ML) phylogenetic analysis using Garli ver. 2.1 (Zwickl 2006) with the optimal tree inferred from 500 replicates. Robustness was assessed with 500 bootstrap replicates summarized in a 50\% majority rule consensus tree calculated with PAUP* ver. $4.0 \mathrm{~b} 10$ (Swofford 2002). The best fitting models for a Bayesian analysis conducted in MrBayes ver. 3.2.3 (Ronquist et al. 2012) with its more restricted model collection were GTR $+\mathrm{I}+\mathrm{G}\left(\mathrm{COI}, 1^{\text {st }}\right.$ codon position), $\mathrm{HKY}+\mathrm{I}\left(2^{\text {nd }}\right.$ position), $\mathrm{TVM}+\mathrm{G}\left(3^{\text {rd }}\right.$ position $)$ and $\mathrm{HKY}+\mathrm{I}+\mathrm{G}(16 \mathrm{~S})$. MrBayes was run for 2 Mio generations with every $100^{\text {th }}$ tree sampled, a burnin of 5000 and otherwise default settings. The average standard deviation of split frequencies reached 0.0046, effective sample sizes exceeded 200, and the potential scale reduction factors reached or closely approached one for all parameters indicating convergence of all estimates. 
Pairwise uncorrected genetic distances were computed after pairwise deletion of missing data for COI in MEGA X (Kumar et al. 2018). For the four new species, we identified diagnostic molecular characters based on the alignments of COI (Electronic Supplement 1) and 16S (Electronic Supplement 2) using QUIDDICH (Kühn \& Haase 2020), a package written in R (R Core Team 2020). In these diagnoses, we compared each new species of Catapyrgus and Obtusopyrgus to their respective only other congeneric species sequenced or known so far, and the two new species of Opacuincola to all other congeneric species. Among the latter new species, one was also compared to its sister species. The other one did not have a single sister species in our analyses.

All new sequences were deposited at NCBI GenBank under the accession numbers MT651500MT651511 (16S) and MT654586-MT654595 (COI).

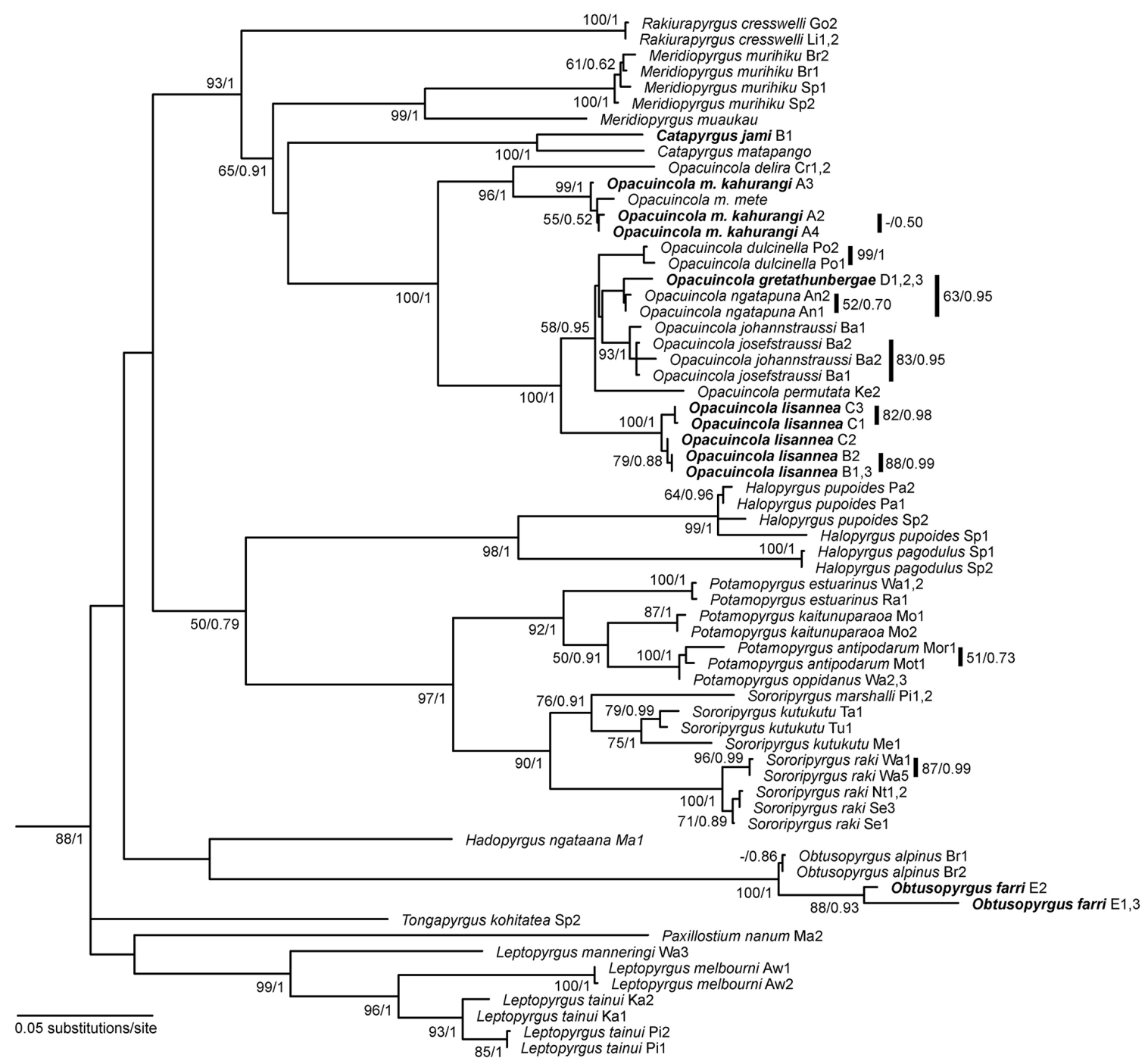

Fig. 2. Phylogenetic analysis. Maximum likelihood tree with bootstrap support $>50$ / posterior probabilities from Bayesian analysis $>0.50$ for nodes. New taxa in bold. Letters A-E after new taxa refer to localities in Figure 1. 
Table 1 (continued on next page). Morphometrics of new taxa. A-E following the names refer to the localities in Figure 1. Abbreviations: $\mathrm{AH}=$ aperture height; $\mathrm{AW}=$ aperture width; BWW = bodywhorl width; $\mathrm{CV}=$ coefficient of variation corrected for unequal sample sizes; $\max =$ maximum; $\min$ = minimum; $\mathrm{SD}=$ standard deviation; $\mathrm{SH}=$ shell height; $\mathrm{SW}=$ shell width; $\mathrm{W}=$ number of whorls. Measurements in $\mathrm{mm}$.

\begin{tabular}{|c|c|c|c|c|c|c|c|}
\hline Species & SH & SW & BWW & $\mathbf{A H}$ & AW & SH/SW & W \\
\hline \multicolumn{8}{|c|}{$\begin{array}{l}\text { Catapyrgus jami } \mathrm{B} \\
\mathrm{N}=9\end{array}$} \\
\hline Holotype & 1.63 & 0.92 & 0.82 & 0.60 & 0.55 & 1.77 & 4.25 \\
\hline $\min$ & 1.44 & 0.85 & 0.73 & 0.52 & 0.50 & 1.62 & 3.88 \\
\hline $\max$ & 1.71 & 1.06 & 0.85 & 0.63 & 0.56 & 1.77 & 4.25 \\
\hline mean & 1.55 & 0.91 & 0.78 & 0.57 & 0.53 & 1.70 & 4.04 \\
\hline median & 1.52 & 0.89 & 0.77 & 0.57 & 0.52 & 1.70 & 4.00 \\
\hline $\mathrm{SD}$ & 0.09 & 0.06 & 0.04 & 0.03 & 0.02 & 0.04 & 0.14 \\
\hline $\mathrm{CV}$ & 6.03 & 6.72 & 5.66 & 5.91 & 4.13 & 2.67 & 3.56 \\
\hline \multicolumn{8}{|c|}{$\begin{array}{l}\text { Opacuincola lisannea } \mathrm{B} \\
\mathrm{N}=20\end{array}$} \\
\hline Holotype & 2.60 & 1.30 & 1.14 & 0.88 & 0.85 & 2.00 & 4.38 \\
\hline $\min$ & 2.02 & 1.03 & 1.00 & 0.78 & 0.70 & 1.61 & 3.75 \\
\hline $\max$ & 2.60 & 1.33 & 1.22 & 0.92 & 0.85 & 2.07 & 4.38 \\
\hline mean & 2.24 & 1.23 & 1.09 & 0.84 & 0.80 & 1.83 & 4.13 \\
\hline median & 0.22 & 1.23 & 1.10 & 0.83 & 0.80 & 1.80 & 4.13 \\
\hline $\mathrm{SD}$ & 0.12 & 0.06 & 0.05 & 0.04 & 0.04 & 0.10 & 0.16 \\
\hline $\mathrm{CV}$ & 5.58 & 5.32 & 4.82 & 5.02 & 4.88 & 5.40 & 3.92 \\
\hline \multicolumn{8}{|c|}{$\begin{array}{l}\text { Opacuincola lisannea } \mathrm{C} \\
\mathrm{N}=17\end{array}$} \\
\hline $\min$ & 1.87 & 1.06 & 0.93 & 0.68 & 0.71 & 1.68 & 3.75 \\
\hline $\max$ & 2.36 & 1.32 & 1.10 & 0.89 & 0.83 & 1.93 & 4.25 \\
\hline mean & 2.10 & 1.17 & 1.03 & 0.79 & 0.78 & 1.79 & 4.09 \\
\hline median & 2.07 & 1.17 & 1.03 & 0.79 & 0.79 & 1.77 & 4.13 \\
\hline $\mathrm{SD}$ & 0.14 & 0.07 & 0.05 & 0.05 & 0.04 & 0.07 & 0.14 \\
\hline $\mathrm{CV}$ & 6.61 & 5.90 & 5.22 & 6.39 & 4.77 & 3.72 & 3.47 \\
\hline \multicolumn{8}{|c|}{$\begin{array}{l}\text { Opacuincola gretathunbergae } \mathrm{D} \\
\mathrm{N}=20\end{array}$} \\
\hline Holotype & 2.19 & 1.33 & 1.06 & 0.91 & 0.88 & 1.65 & 3.63 \\
\hline $\min$ & 2.07 & 1.26 & 1.04 & 0.84 & 0.79 & 1.57 & 3.50 \\
\hline $\max$ & 2.74 & 1.63 & 1.31 & 1.08 & 1.04 & 1.77 & 4.25 \\
\hline mean & 2.35 & 1.41 & 1.16 & 0.95 & 0.89 & 1.66 & 3.96 \\
\hline median & 2.36 & 1.40 & 1.17 & 0.93 & 0.88 & 1.65 & 4.00 \\
\hline $\mathrm{SD}$ & 0.18 & 0.11 & 0.08 & 0.07 & 0.06 & 0.07 & 0.23 \\
\hline $\mathrm{CV}$ & 7.84 & 7.52 & 6.93 & 7.11 & 6.65 & 4.08 & 5.88 \\
\hline \multicolumn{8}{|c|}{$\begin{array}{l}\text { Opacuincola mete kahurangi } \mathrm{A} \\
\mathrm{N}=20\end{array}$} \\
\hline Holotype & 2.13 & 1.85 & 1.32 & 1.21 & 1.09 & 1.15 & 3.13 \\
\hline
\end{tabular}


Table 1. (continued).

\begin{tabular}{llllllll}
\hline Species & SH & SW & BWW & AH & AW & SH/SW & W \\
\hline min & 1.85 & 1.45 & 1.12 & 0.95 & 0.89 & 1.06 & 3.13 \\
max & 2.44 & 2.04 & 1.50 & 1.35 & 1.22 & 1.31 & 4.00 \\
mean & 2.21 & 1.83 & 1.36 & 1.19 & 1.06 & 1.21 & 3.39 \\
median & 2.24 & 1.85 & 1.38 & 1.21 & 1.07 & 1.20 & 3.31 \\
SD & 0.15 & 0.14 & 0.09 & 0.11 & 0.09 & 0.06 & 0.25 \\
CV & 7.02 & 7.63 & 6.89 & 9.08 & 8.68 & 4.81 & 7.47 \\
Obtusopyrgus farri E & & & & & & & \\
N = 20 & & & & & & & \\
Holotype & 2.24 & 1.28 & 1.16 & 0.80 & 0.81 & 1.75 & 4.13 \\
min & 2.00 & 1.19 & 1.07 & 0.75 & 0.74 & 1.63 & 3.63 \\
max & 2.31 & 1.32 & 1.18 & 0.87 & 0.86 & 1.87 & 4.25 \\
mean & 2.15 & 1.25 & 1.12 & 0.80 & 0.79 & 1.73 & 3.95 \\
median & 2.14 & 1.24 & 1.12 & 0.79 & 0.79 & 1.72 & 4.00 \\
SD & 0.08 & 0.04 & 0.03 & 0.03 & 0.03 & 0.06 & 0.17 \\
CV & 3.98 & 3.01 & 2.81 & 3.75 & 3.83 & 3.66 & 4.36 \\
\hline
\end{tabular}

\section{Results}

\section{Phylogeny}

The phylogenetic analyses (Fig. 2) recovered the major clades from previous analyses (Haase 2005, 2008; Zielske et al. 2017). Their relationships were slightly different, however, basally unsupported. All genera received high bootstrap support as well as posterior probabilities and all new taxa unambiguously fell into one of three known genera, viz. Catapyrgus, Opacuincola and Obtusopyrgus, respectively. According to these reconstructions, the four new species were well differentiated against respective congeneric species. Only the taxon found along the Fenian track was paraphyletic with respect to Opacuincola mete Haase, 2008. This was one reason why it was classified as a subspecies of the latter (see below).

\section{Shell morphology}

Overall shell morphology was compared in a PCA(Fig. 3) based on the five shell measurements (Table 1). The first two components already explained $98.8 \%$ of the variation $(90.1 \%$ and $8.7 \%$, respectively). Component one was dominated by shell size, with negative scores for small and positive scores for large values. Component two largely reflected shell shape, with negative loading for shell height and positive weight for shell width. Thus, slender shells had negative scores and broad conical ones positive ones. Catapyrgus jami sp. nov. largely overlapped with C. matapango and also both species of Obtusopyrgus were hard to separate based on shell morphology. Similarly, the clusters of the only new species represented by two samples, Op. lisannea sp. nov., overlapped to a high degree. All other new taxa formed clusters clearly separated from the respective most similar species selected for comparison. The comparisons involving Op. mete and Op. ngatapuna, of which only two individuals were available for each, would not change much considering the dimensions of these species given in Haase (2008). Not unexpectedly, genera could not be distinguished based on shell dimensions. 
Table 2. Diagnostic alignment positions. All characters are of type 1, i.e., they are fixed in a particular taxon. Positions refer to the alignments of COI and 16S rRNA in Electronic Supplements 1 and 2, respectively. Position 382 in bold is the only diagnostic position for Opacuincola gretathunbergae across all samples of the genus. Therefore, it was also compared to its sister species Op. ngatapuna. In Ob. farri, sequencing of COI failed.

\begin{tabular}{|c|c|c|c|c|c|c|c|c|c|c|c|c|c|c|c|c|c|c|c|c|c|c|c|c|}
\hline Species & Gene & & & & & & & & & & & siti & on $/ \mathrm{S}$ & tat & & & & & & & & & & \\
\hline & COI & 0 & 0 & 0 & 0 & 0 & 0 & 0 & 0 & 0 & 1 & 1 & 1 & 1 & 1 & 2 & 2 & 2 & 2 & 2 & 2 & 2 & 2 & 2 \\
\hline & & 1 & 4 & 4 & 5 & 7 & 7 & 7 & 8 & 9 & 0 & 6 & 6 & 7 & 8 & 0 & 0 & 1 & 2 & 3 & 3 & 4 & 5 & 6 \\
\hline & & 3 & 3 & 9 & 8 & 3 & 6 & 9 & 2 & 4 & 3 & 3 & 9 & 5 & 4 & 2 & 8 & 4 & 6 & 2 & 8 & 4 & 0 & 2 \\
\hline C. jami & & $\mathrm{C}$ & $\mathrm{C}$ & $\mathrm{T}$ & $\mathrm{C}$ & G & A & $\mathrm{T}$ & G & G & G & $\mathrm{T}$ & G & G & A & $\mathrm{C}$ & $\mathrm{C}$ & $\mathrm{C}$ & G & $\mathrm{C}$ & G & $\mathrm{T}$ & G & A \\
\hline C. matapango & & $\mathrm{T}$ & $\mathrm{T}$ & $\mathrm{C}$ & $\mathrm{T}$ & A & G & A & A & A & A & $\mathrm{C}$ & A & A & G & $\mathrm{T}$ & $\mathrm{T}$ & $\mathrm{T}$ & $\mathrm{T}$ & $\mathrm{T}$ & A & $\mathrm{C}$ & A & G \\
\hline & COI & 2 & 3 & 3 & 3 & 3 & 3 & 3 & 3 & 4 & 4 & 4 & 4 & 5 & 5 & 5 & 6 & 6 & 6 & 6 & 6 & 6 & 6 & \\
\hline & & 6 & 0 & 2 & 3 & 3 & 4 & 5 & 7 & 0 & 3 & 6 & 7 & 1 & 4 & 8 & 1 & 1 & 1 & 2 & 2 & 2 & 4 & \\
\hline & & 5 & 7 & 2 & 4 & 7 & 1 & 5 & 0 & 6 & 0 & 0 & 2 & 7 & 7 & 9 & 0 & 6 & 9 & 2 & 5 & 8 & 0 & \\
\hline C. jami & & A & $\mathrm{C}$ & $\mathrm{G}$ & $\mathrm{C}$ & $\mathrm{C}$ & $\mathrm{T}$ & $\mathrm{C}$ & $\mathrm{C}$ & A & A & G & $\mathrm{C}$ & $\mathrm{T}$ & $\mathrm{C}$ & $\mathrm{T}$ & $\mathrm{C}$ & $\mathrm{T}$ & A & $\mathrm{C}$ & G & $\mathrm{C}$ & $\mathrm{T}$ & \\
\hline C. matapango & & G & $\mathrm{T}$ & A & $\mathrm{T}$ & $\mathrm{T}$ & $\mathrm{C}$ & $\mathrm{T}$ & $\mathrm{T}$ & G & G & A & $\mathrm{T}$ & $\mathrm{C}$ & $\mathrm{T}$ & $\mathrm{C}$ & $\mathrm{T}$ & $\mathrm{C}$ & $\mathrm{G}$ & G & $\mathrm{T}$ & $\mathrm{T}$ & $\mathrm{C}$ & \\
\hline & $16 \mathrm{~S}$ & 1 & 1 & 2 & 2 & 2 & 2 & 2 & 2 & 2 & 2 & 3 & 3 & 3 & 4 & & & & & & & & & \\
\hline & & 1 & 5 & 2 & 2 & 2 & 3 & 4 & 4 & 4 & 9 & 0 & 1 & 1 & 4 & & & & & & & & & \\
\hline & & 9 & 2 & 5 & 6 & 9 & 9 & 3 & 8 & 9 & 1 & 9 & 1 & 2 & 9 & & & & & & & & & \\
\hline C. jami & & G & $\mathrm{C}$ & A & $\mathrm{T}$ & A & - & A & A & $\mathrm{C}$ & $\mathrm{C}$ & $\mathrm{C}$ & $\mathrm{T}$ & $\mathrm{C}$ & $\mathrm{T}$ & & & & & & & & & \\
\hline C. matapango & & A & $\mathrm{T}$ & G & $\mathrm{C}$ & $\mathrm{T}$ & A & G & G & $\mathrm{T}$ & $\mathrm{T}$ & $\mathrm{T}$ & $\mathrm{C}$ & $\mathrm{T}$ & G & & & & & & & & & \\
\hline & COI & 0 & 1 & 1 & 2 & 2 & 2 & 3 & 4 & 4 & 5 & 5 & 5 & 6 & 6 & & & & & & & & & \\
\hline & & 8 & 1 & 9 & 6 & 8 & 8 & 0 & 1 & 6 & 0 & 8 & 9 & 0 & 2 & & & & & & & & & \\
\hline & & 9 & 2 & 0 & 5 & 6 & 9 & 7 & 5 & 9 & 2 & 9 & 8 & 7 & 8 & & & & & & & & & \\
\hline Op. lisannea & & $\mathrm{C}$ & $\mathrm{C}$ & $\mathrm{G}$ & $\mathrm{C}$ & $\mathrm{G}$ & G & $\mathrm{C}$ & $\mathrm{T}$ & $\mathrm{C}$ & G & $\mathrm{C}$ & $\mathrm{C}$ & $\mathrm{C}$ & $\mathrm{C}$ & & & & & & & & & \\
\hline & $16 \mathrm{~S}$ & 1 & 3 & 3 & 3 & 3 & 3 & & & & & & & & & & & & & & & & & \\
\hline & & 6 & 0 & 1 & 1 & 2 & 2 & & & & & & & & & & & & & & & & & \\
\hline & & 5 & 7 & 3 & 9 & 0 & 6 & & & & & & & & & & & & & & & & & \\
\hline Op. lisannea & & G & G & - & G & $\mathrm{C}$ & A & & & & & & & & & & & & & & & & & \\
\hline & COI & 0 & 0 & 0 & 0 & 2 & 2 & 3 & 6 & & & & & & & & & & & & & & & \\
\hline & & 0 & 3 & 7 & 8 & 0 & 8 & 8 & 2 & & & & & & & & & & & & & & & \\
\hline & & 7 & 7 & 3 & 2 & 2 & 9 & 2 & 2 & & & & & & & & & & & & & & & \\
\hline Op. gretathun- & & $\mathrm{C}$ & A & $\mathrm{G}$ & A & A & $\mathrm{T}$ & G & $\mathrm{G}$ & & & & & & & & & & & & & & & \\
\hline bergae & & & & & & & & & & & & & & & & & & & & & & & & \\
\hline Op. ngatapuna & & $\mathrm{T}$ & G & $\mathrm{A}$ & G & G & $\mathrm{C}$ & $\mathrm{A}$ & A & & & & & & & & & & & & & & & \\
\hline & $16 \mathrm{~S}$ & 1 & 3 & 3 & & & & & & & & & & & & & & & & & & & & \\
\hline & & 5 & 0 & 2 & & & & & & & & & & & & & & & & & & & & \\
\hline & & 6 & 9 & 9 & & & & & & & & & & & & & & & & & & & & \\
\hline Op. gretathun- & & G & $\mathrm{C}$ & $\mathrm{G}$ & & & & & & & & & & & & & & & & & & & & \\
\hline bergae & & & & & & & & & & & & & & & & & & & & & & & & \\
\hline Op. ngatapuna & & A & $\mathrm{T}$ & A & & & & & & & & & & & & & & & & & & & & \\
\hline & $16 \mathrm{~S}$ & 1 & 1 & 2 & 2 & 3 & & & & & & & & & & & & & & & & & & \\
\hline & & 0 & 7 & 1 & 4 & 2 & & & & & & & & & & & & & & & & & & \\
\hline & & 7 & 6 & 5 & 9 & 1 & & & & & & & & & & & & & & & & & & \\
\hline Ob. farri & & $\mathrm{C}$ & G & $\mathrm{T}$ & A & A & & & & & & & & & & & & & & & & & & \\
\hline Ob. alpinus & & $\mathrm{T}$ & A & $\mathrm{C}$ & G & G & & & & & & & & & & & & & & & & & & \\
\hline
\end{tabular}




\section{Systematic descriptions}

The summary statistics of the shell parameters of the new taxa are given in Table 1 and not repeated in the descriptions. Anatomical information is based on the specimens prepared for SEM and on the $\mu \mathrm{CT}$ scans, i.e., in total up to three specimens of each sex. Diagnostic molecular characters for the four new species are provided in Table 2 .

Phylum Mollusca Linnaeus, 1758

Class Gastropoda Cuvier, 1795

Subclass Caenogastropoda Cox, 1960

Family Tateidae Thiele, 1925

Genus Catapyrgus Climo, 1974

Catapyrgus jami sp. nov.

urn:1sid:zoobank.org:act:98955097-7D04-4822-8408-30E37B79766B

Figs 4A-B, 5A, 6A, 7, 8A, 9; Tables 1-2

\section{Diagnosis}

Catapyrgus jami sp. nov. is most similar to C. matapango, however but is, genetically distinct at 59 alignment positions. Furthermore, it differs from its congeners in the shape of the bursa copulatrix, which is globular rather than kidney-shaped.

\section{Etymology}

Catapyrgus jami sp. nov. is named after Jochen A. Modeß, musician and composer who until his retirement from the university in 2019 has significantly shaped the cultural life of the city of Greifswald for over 25 years. The name is based on the initials of the dedicatee.

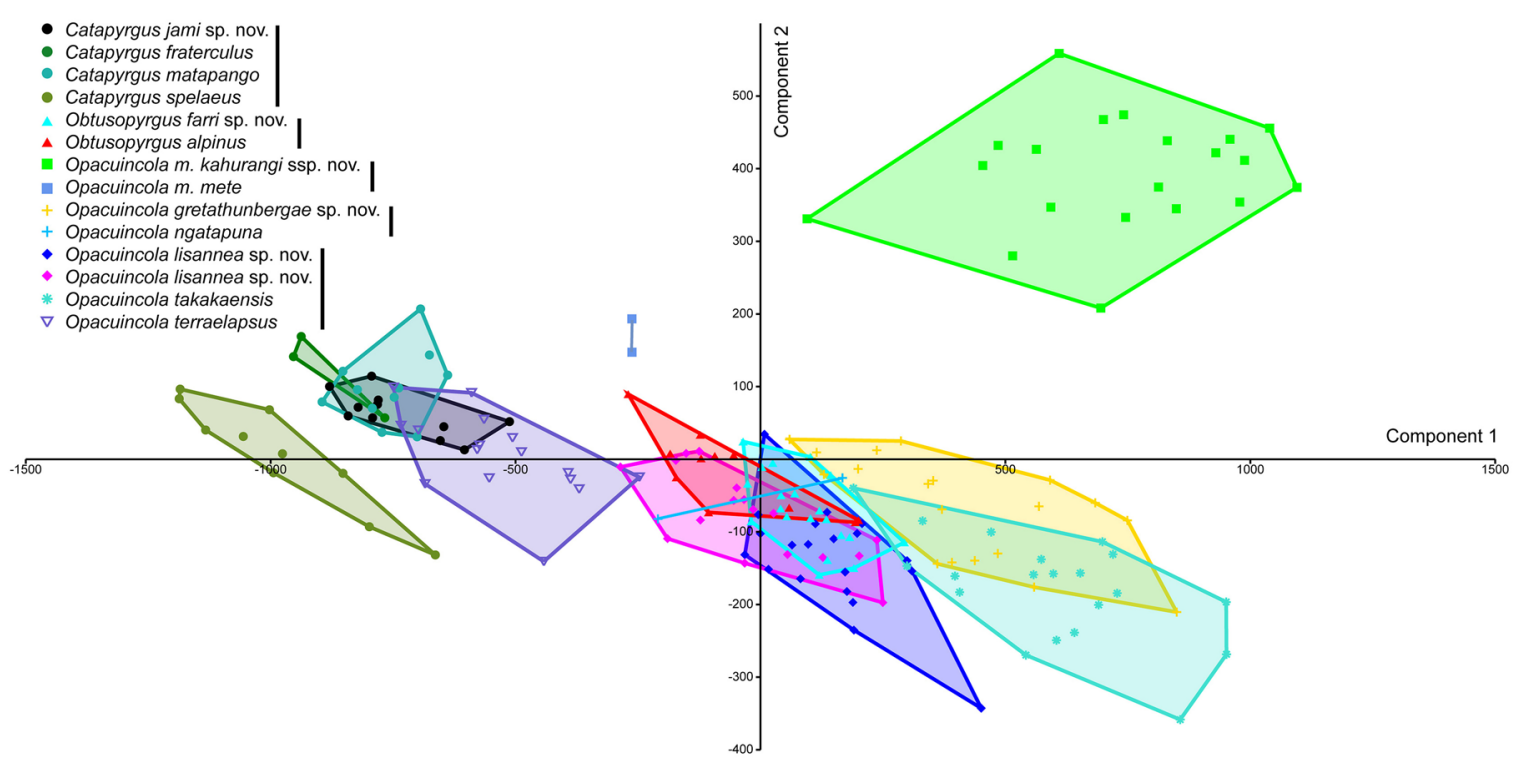

Fig. 3. Shell morphology. Principal component analysis based on five shell measurements of Table 1. 


\section{Material examined}

Holotype (Fig. 4A)

NEW ZEALAND - Kahurangi National Park, SW of Collingwood, Kaituna Track; 4042'36.3" S, 172³3'36.3" E; 28 Feb. 2016; G. Verhaegen and M. Haase leg.; on leaves, stones, woody debris in small spring; NMNZ.M.330187.

\section{Paratypes (Fig. 4B)}

NEW ZEALAND • 9 specs; same collection data as for holotype; NMNZ.M.330188.

\section{Description}

SHELl (Figs 4A-B, 5A). Short turriform, about 1.7 times as high as than wide, white-translucent with light brown periostracum; protoconch with fine pits comprising 0.75 whorls (Fig. 6A); entire shell with 3.875 to 4.25 whorls without structure apart from growth lines; umbilicus narrow; aperture orthocline, almost circular, only slightly higher than wide.

OperCulum (Fig. 7). Yellowish to light orange, paucispiral; with non-calcareous white peg in submarginal nucleus.

EXTERNAL FEATURES. Epidermis without pigment; eyes small with bean-shaped pigment spot; tentacles without particular ciliation.

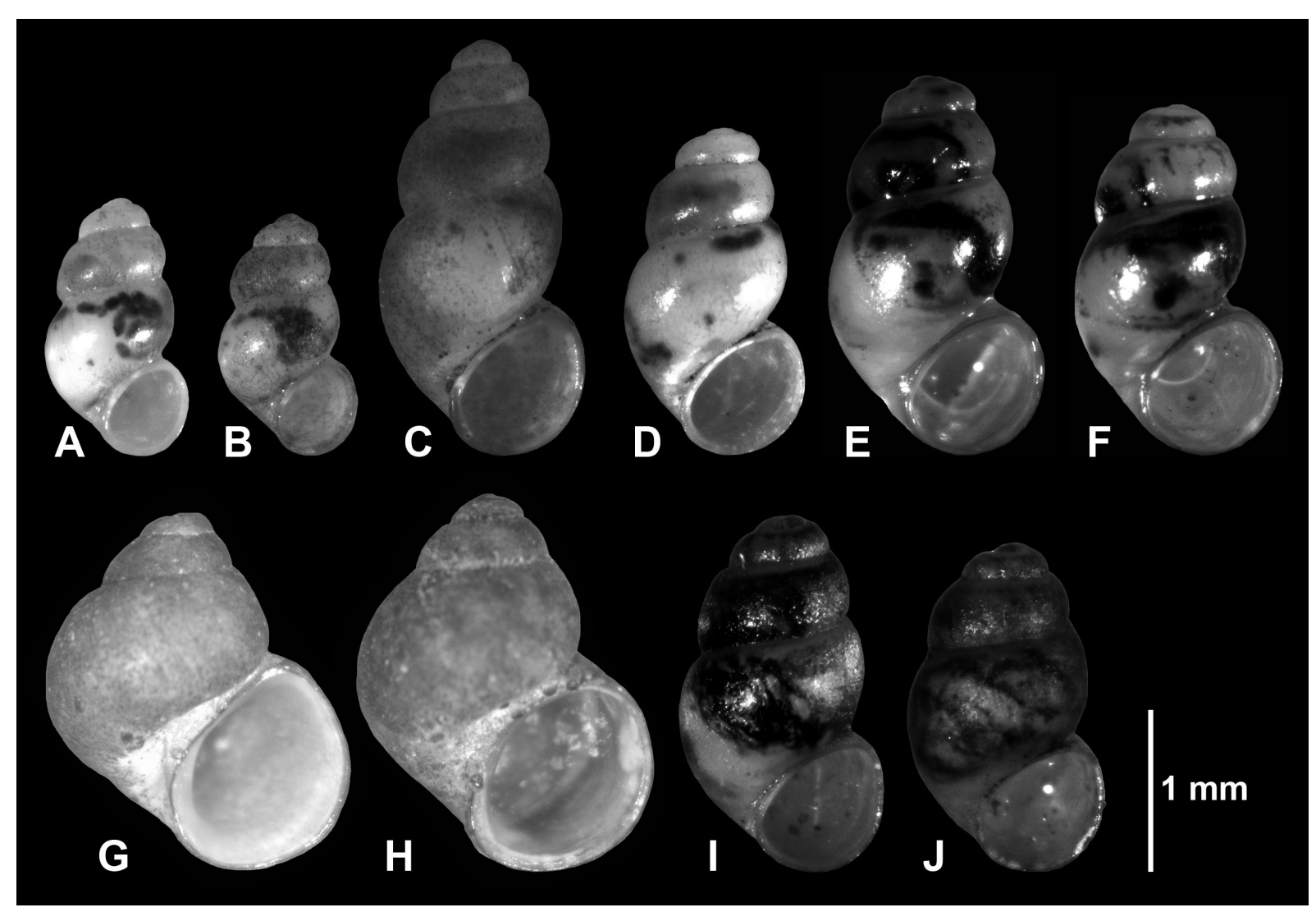

Fig. 4. Types. A-B. Catapyrgus jami sp. nov. C-D. Opacuincola lisannea sp. nov. (D from northern locality). E-F. Op. gretathunbergae sp. nov. G-H. Op. mete kahurangi subsp. nov. I-J. Obtusopyrgus farri sp. nov. A, C, E, G, I, holotypes, rest paratypes. 
MANTLE CAVITY. No ctenidial filaments; osphradium ovate-elongate.

Digestive system. Radula has formula R 5-6 1 5-6/2 2, L 4-5 1 7, M1 25-29, M2 22-24 (Fig. 8A); stomach without caecum; intestine makes narrow, long coil in roof of mantle cavity.

Female Genitalia $(\mathrm{n}=3$; Fig 9A). Ovary short, simple sac not reaching stomach; renal oviduct first coiling $180^{\circ}$ clockwise, then $270^{\circ}$ counter-clockwise; one small, distal receptaculum seminis; bursa copulatrix globular, behind albumen gland, bursal duct entering ventrally; ovoviviparous, brooding at least one embryo in pallial oviduct, pallial oviduct as brood pouch with albumen gland as well as capsule gland with a larger posterior and short anterior section.

Male genitalia ( $\mathrm{n}=1$; Fig. 9B). Testis sac with short lobes, starting more than one whorl below apex, comprises ca 0.5 whorl, anteriorly just reaching stomach; vesicula seminalis coils along anterior half of testis; proximal and distal vasa deferentia insert closely in about middle of flat pear-shaped prostate; penis slender, unclear from CT-scans whether it has a lobe or not.

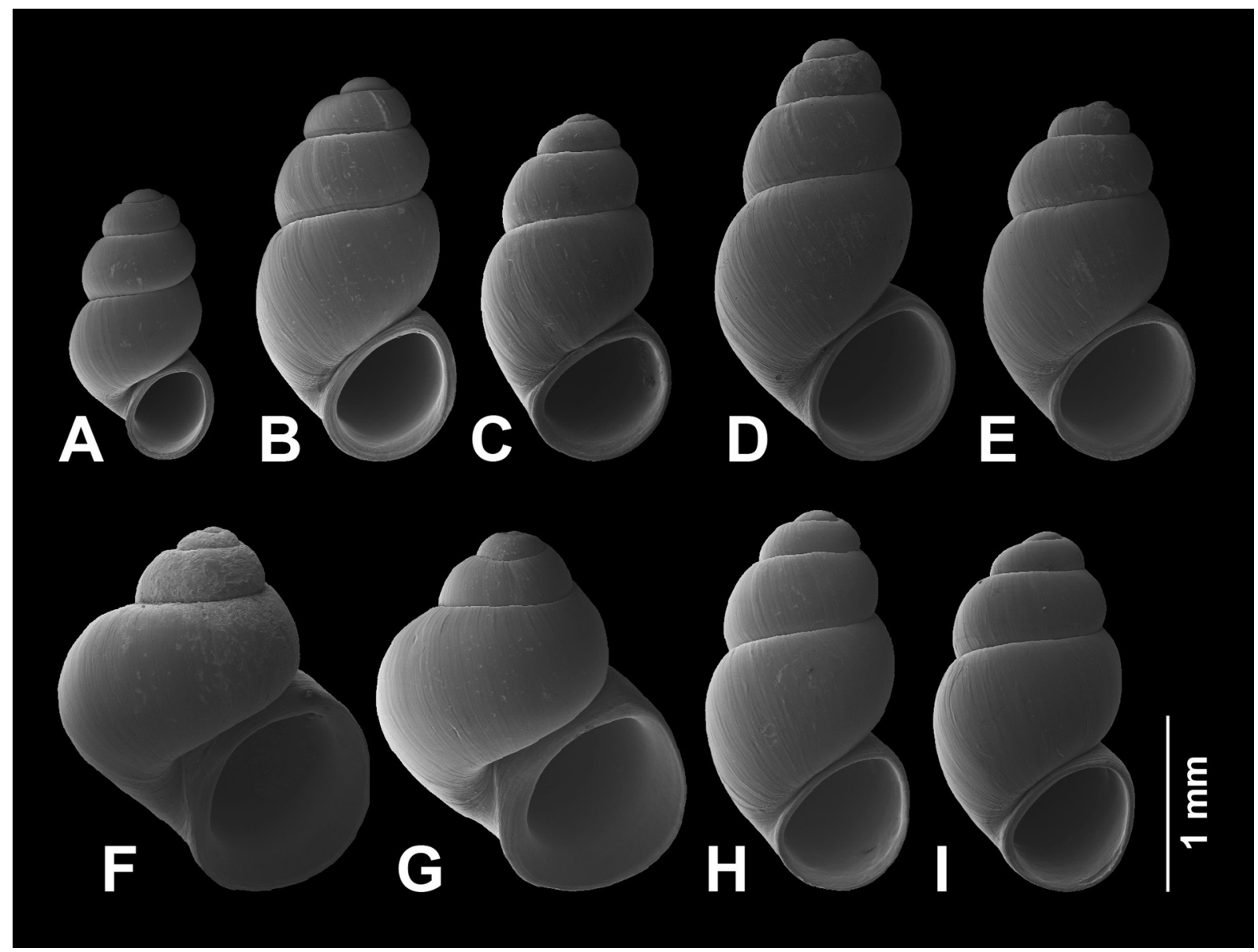

Fig. 5. Shells. SEM photographs of paratypes. A. Catapyrgus jami sp. nov. B-C. Opacuincola lisannea sp. nov. (B, topotype; C, northern locality). D-E. Op. gretathunbergae sp. nov. F-G. Op. mete kahurangi subsp. nov. H-I. Obtusopyrgus farri sp. nov. 


\section{Remarks}

Catapyrgus jami sp. nov. is most similar to C. matapango in terms of shell size and shape (Fig. 3). The latter is the only other species of the genus for which sequence data exist. The divergence of the species was fairly large (Fig. 2) with a COI p-distance of 0.07 , and 45 and 14 diagnostic characters in COI and $16 \mathrm{~S}$, respectively (Table 2). The reduced eyes suggest that this species dwells in the transition zone of epigean and ground waters. The new species occurred sympatrically with $O p$. lisannea sp. nov.

Genus Opacuincola Ponder, 1966

Opacuincola lisannea sp. nov. urn:lsid:zoobank.org:act:FD252AD2-B0D4-4996-9F13-38F4002D5CA6

Figs 4C-D, 5B-C, 6B-C, 8B, 10, 11A; Tables 1-2

\section{Diagnosis}

The new species is a slender-conical Opacuincola most similar to the smaller Op. terraelapsus. Opacuincola takakaensis is larger and more conical. Compared to Op. terraelapsus, the new species has a larger bursa copulatrix reaching much farther behind the albumen gland than in the latter, and the huge penis has no subterminal swelling and has a lobe that points forward rather than to the right. Compared to all other congeners, Op. lisannea sp. nov. had 20 diagnostic DNA positions.

\section{Etymology}

Opacuincola lisannea sp. nov. is dedicated to Lisanne Verhaegen, the sister of the first author, on the occasion of her $30^{\text {th }}$ birthday. She is in part responsible for the debut of the first author as a biologist by proofreading numerous of her applications, including the one for her $\mathrm{PhD}$ position, resulting in the discovery of this new species.

\section{Material examined}

Holotype (Fig. 4C)

NEW ZEALAND - Kahurangi National Park, SW of Collingwood, Kaituna Track; 40²' $36.3^{\prime \prime}$ S, $172^{\circ} 33^{\prime} 36.3^{\prime \prime}$ E; 28 Feb. 2016; G. Verhaegen and M. Haase leg.; on leaves, stones, woody debris in small spring; NMNZ.M.330189.

Paratypes (Figs 4D, 5B-C)

NEW ZEALAND • 19 specs; same collection data as for holotype; NMNZ.M.330190 • 14; Kahurangi National Park, SW of Collingwood, Kaituna Track; 4042'30.5" S, 172 ${ }^{\circ} 33^{\prime} 50.9^{\prime \prime}$ E; 28 Feb. 2016; G. Verhaegen and M. Haase leg.; on leaves, stones, woody debris in small spring; NMNZ.M.330201.

\section{Description}

SHell (Figs 4C-D, 5B-C). Slender-conical to pupiform, about 1.8 times as high as than wide, whitetranslucent with light brown periostracum; protoconch with fine pits comprising ca 0.85 whorls (Fig. 6BC); entire shell with 3.75 to 4.375 whorls, teleoconch with fine longitudinal ridges on first 0.25 whorl, then without structure apart from growth lines; umbilicus narrow; aperture orthocline, almost circular, only slightly higher than wide.

OPERCULUM. Light orange, paucispiral; nucleus submarginal, without peg.

EXTERNAL FEATURES. Epidermis without pigment; eyes small with bean-shaped pigment spot; tentacles without particular ciliation.

MANTLE CAVITy $(\mathrm{n}=5)$. 9-12 ctenidial filaments; osphradium ovate-elongate, behind middle of gill. 
VERHAEGEN G. \& HAASE M., New tateids from New Zealand

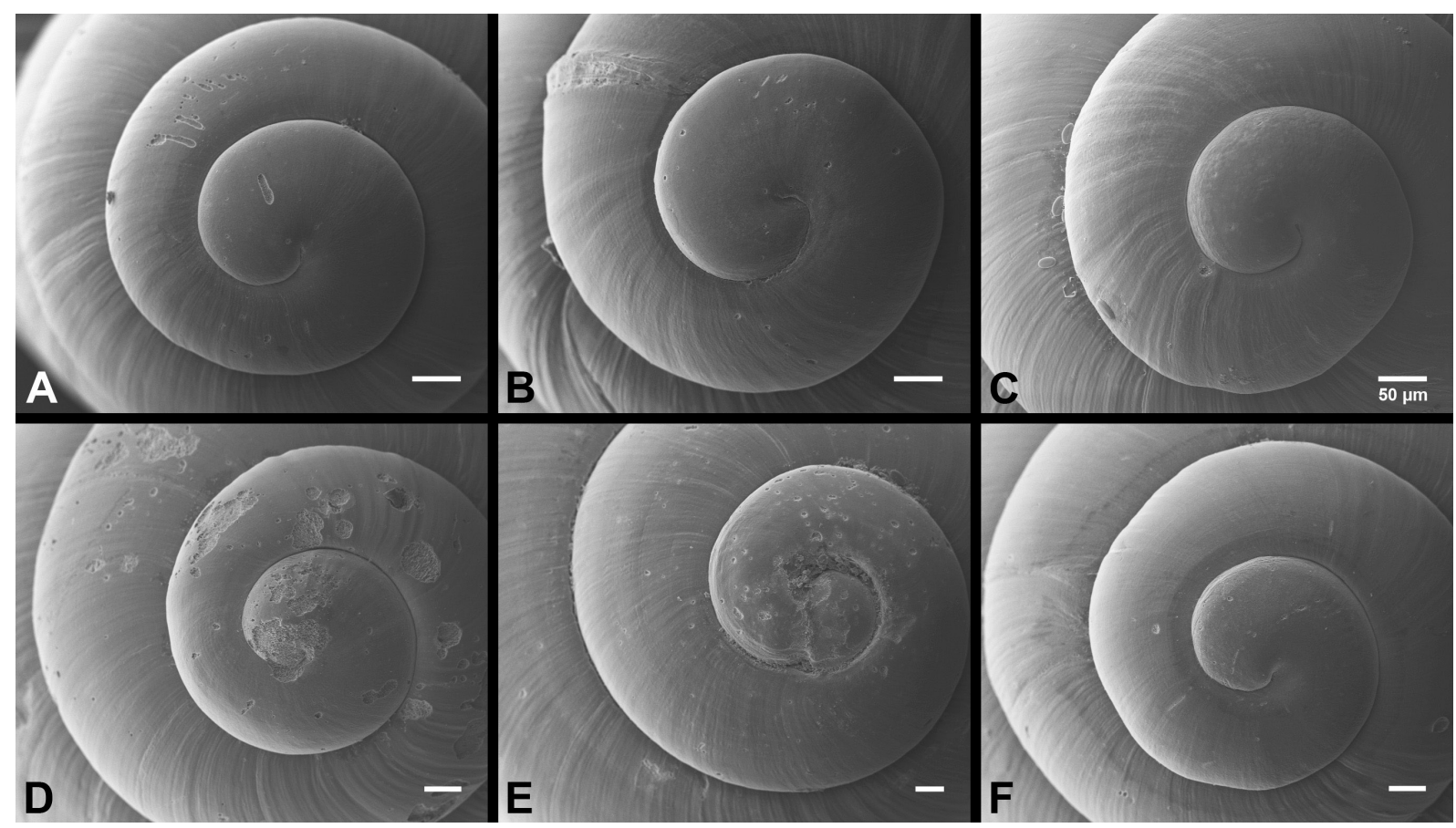

Fig. 6. Protoconch. SEM photographs of paratypes. A. Catapyrgus jami sp. nov. B-C. Opacuincola lisannea sp. nov. (B, topotype; C, northern locality). D. Op. gretathunbergae sp. nov. E. Op. mete kahurangi subsp. nov. F. Obtusopyrgus farri sp. nov.

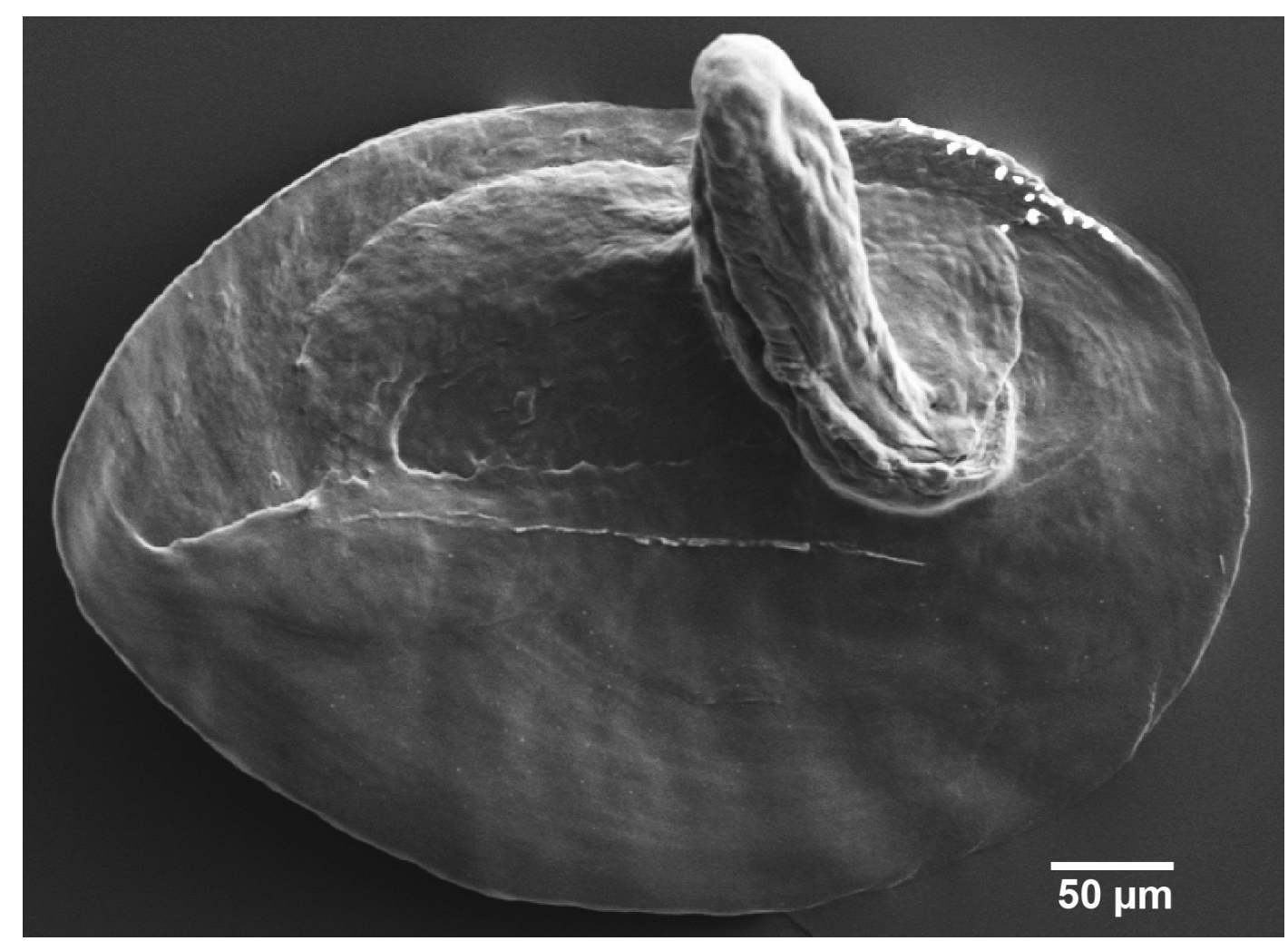

Fig. 7. Operculum of Catapyrgus jami sp. nov. 
Digestive system. Radula has formula R 4-6 1 4-6/3-4 3-4, L 5-6 1 5, M1 23-26, M2 26-33 (Fig. 8B); stomach without caecum; intestine makes loop in roof of mantle cavity, which is clearer in males than in females due to different sizes of pallial genital glands.

Female GenitAlia ( $\mathrm{n}=2$; Fig. 10A). Ovary short, simple sac starting 1.5 whorls below apex, comprising 0.25 whorl and not reaching stomach; renal oviduct first coiling $180^{\circ}$ clockwise, then $270^{\circ}$ counterclockwise; one distal, large receptaculum seminis lying ventrally against bursa copulatrix; bursa copulatrix large, ellipsoid, underneath and reaching far behind albumen gland, bursal duct entering anteriorly; ovoviviparous, brooding at least one embryo in pallial oviduct, pallial oviduct as brood pouch with short albumen gland as well as longer capsule gland, the latter histologically uniform in CT scans.

Male genitalia ( $\mathrm{n}=5$; Fig. 10B). Testis lobate sac, starting ca 0.75 whorl below apex, comprising ca 0.75 whorl, anteriorly just reaching stomach; vesicula seminalis coils along anterior half of testis; proximal vas deferens inserts close to middle of kidney-shaped prostate, distal vas deferens leaving anteriorly; penis large, continuously tapering, ending with broad, cylindrical filament, huge muscular lobe on right side pointing forward (Figs 10B, 11A).

\section{Remarks}

With respect to all other sequenced congeners, Op. lisannea sp. nov. had 14 diagnostic characters in COI and six in 16S, respectively (Table 2). In the phylogeny, it was a well-supported sister species to five

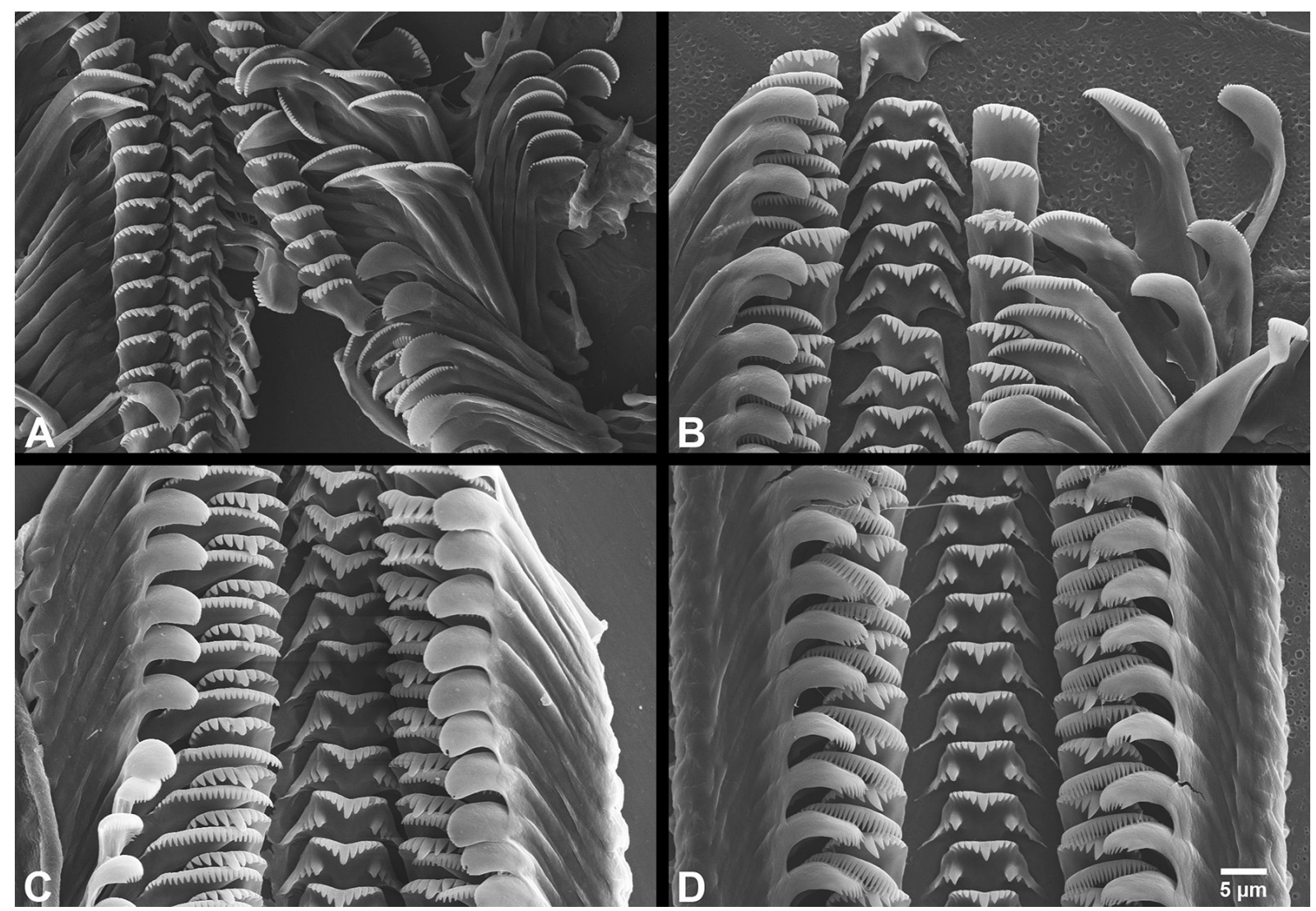

Fig. 8. Radula. SEM photographs. A. Catapyrgus jami sp. nov. B. Opacuincola lisannea sp. nov. (from type locality). C. Op. gretathunbergae sp. nov. D. Obtusopyrgus farri sp. nov. 
other species of the genus (Fig. 2). Morphologically, the new species is most similar to Op. terraelapsus. The latter is smaller (shell height, ANOVA: $\mathrm{df}=2,50 ; \mathrm{F}=79.17 ; \mathrm{p}<0.0001$; Tukey's pairwise posthoc tests: $\mathrm{p}<0.004$ in all three cases), but the species cannot be distinguished in shape (shell height/ shell width, Kruskal-Wallis test: $\mathrm{H}=4.409 ; \mathrm{p}=0.110$; pairwise Mann-Whitney U-tests: $\mathrm{p}>0.05$ in all three cases). This is perfectly reflected in the PCA, where the species largely overlap only along PC2 (Fig. 3). In February 2016, we again failed to find Op. terraelapsus. It was originally collected in
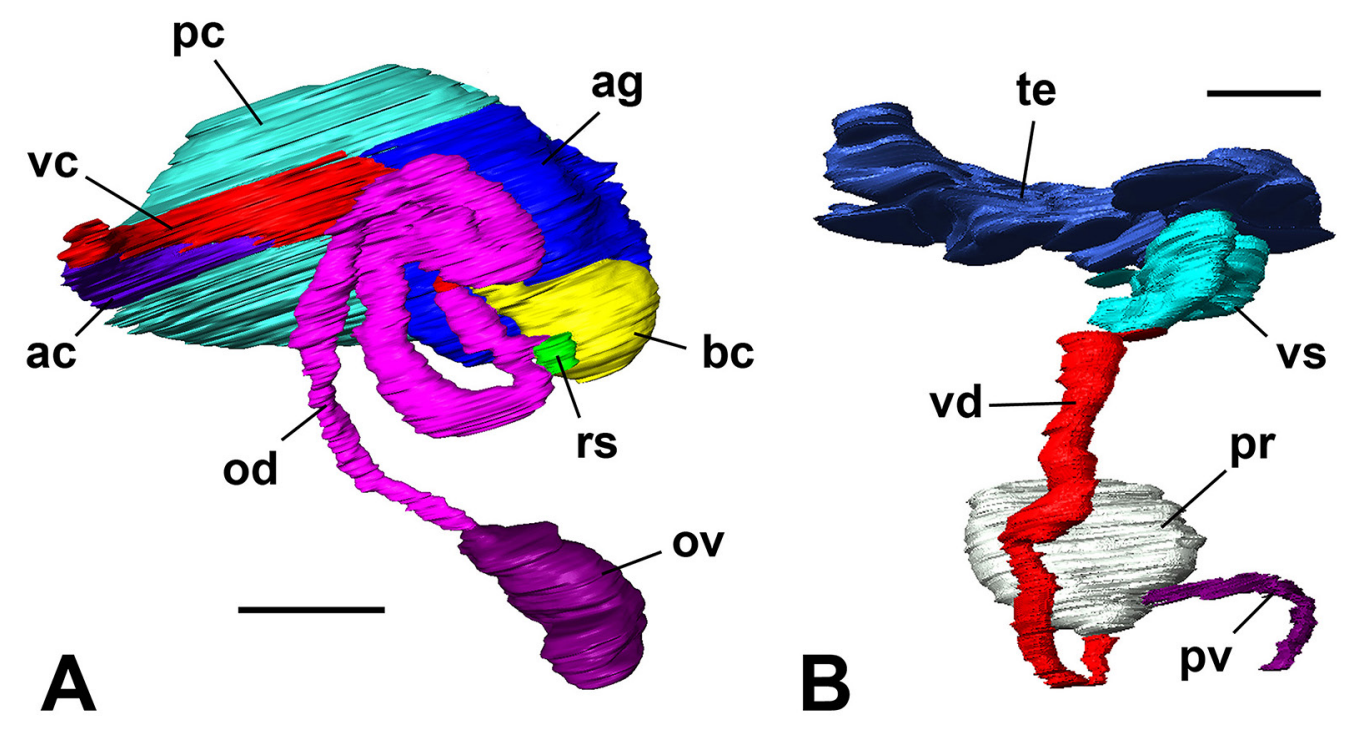

Fig. 9. Genitalia of Catapyrgus jami sp. nov. $\mu \mathrm{CT}$ scans. A. + . B. ${ }^{\lambda}$. Abbreviations: ac $=$ anterior capsule gland; ag = albumen gland; bc = bursa copulatrix; od = oviduct; ov = ovary; $p c=$ posterior capsule gland; $\mathrm{pr}=$ prostate; $\mathrm{pv}=$ pallial vas deferens; $\mathrm{rs}=$ receptaculum seminis; te $=$ testis; $\mathrm{vc}=$ ventral channel; $\mathrm{vd}=$ vas deferens; $\mathrm{vs}=$ vesicula seminalis. Scale bars $=50 \mu \mathrm{m}$.
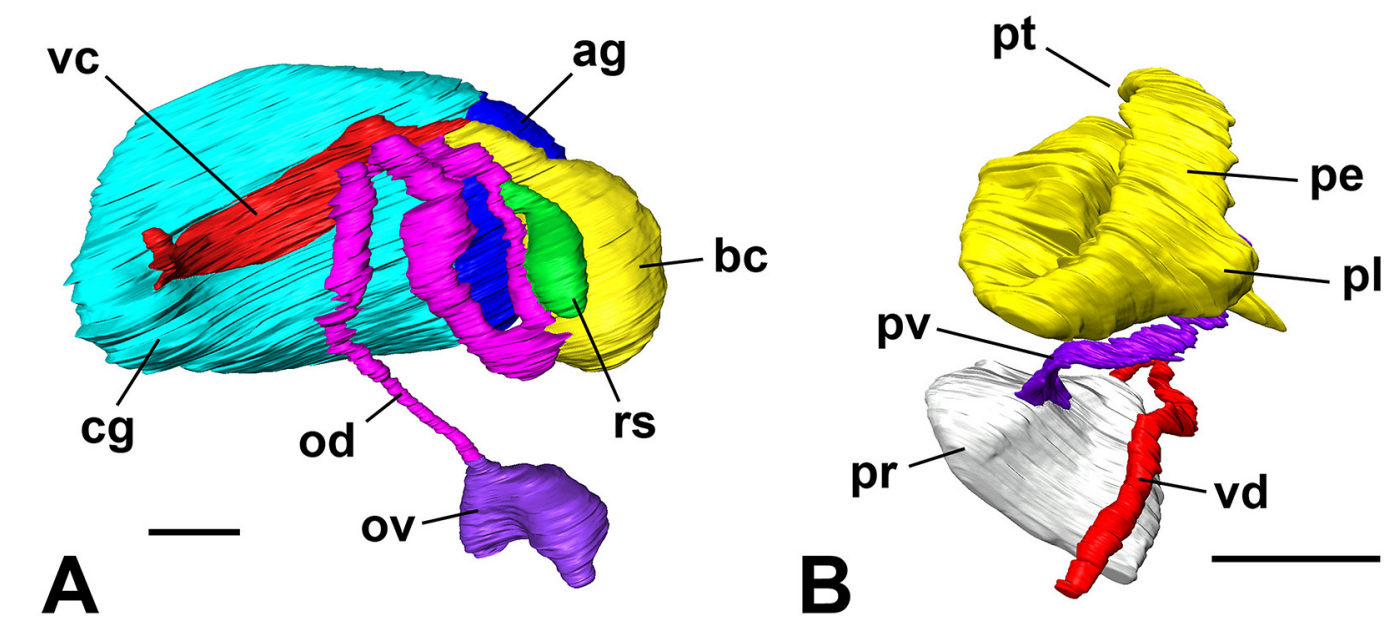

Fig. 10. Genitalia of Opacuincola lisannea sp. nov. $\mu \mathrm{CT}$ scans. A. .. B. $\widehat{\text { B. }}$. Abbreviations: ag = albumen gland; $b c=$ bursa copulatrix; $\mathrm{cg}=$ capsule gland; $\mathrm{od}=$ oviduct; $\mathrm{ov}=$ ovary; $\mathrm{pe}=$ penis; $\mathrm{pl}=$ penial lobe; $\mathrm{pr}=$ prostate $; \mathrm{pt}=$ penial tip; $\mathrm{pv}=$ pallial vas deferens; $\mathrm{rs}=$ receptaculum seminis; $\mathrm{vc}=$ ventral channel; $\mathrm{vd}=$ vas deferens. Scale bars $=50 \mu \mathrm{m}$. 
a trickle somewhere at the start of the Fenian track near Karamea in 1976, blocked by a landslide in 2002 when MH first attempted to relocate this species (see Haase 2008). Whether Op. terraelapsus has survived until today can only be hoped. The reduced eyes suggest that $O p$. lisannea sp. nov. dwells in the transition zone of epigean and ground waters. At the type locality of the new species, we also collected Catapyrgus jami sp. nov.

Opacuincola gretathunbergae sp. nov. urn:lsid:zoobank.org:act:FCAB414F-A55A-4819-AFE1-CE2AF78D6B2F

Figs 4E-F, 5D-E, 6D, 8C, 11B, 12; Tables 1-2

\section{Diagnosis}

The new species is most similar to Op. ngatapuna in terms of shape and epidermal pigmentation. It differs from the latter in 11 diagnostic DNA positions, in being much larger and in penial morphology. The penis and penial lobe of Op. gretathunbergae sp. nov. are considerably more delicate.

\section{Etymology}

The dedicatee of this new species is the Swedish teenage climate activist Greta Thunberg. Starting with a single-person school strike and demonstration to save our climate she has sparked the global movement "Fridays for Future" supported primarily by young people and managed to finally get momentum in global politics toward action against climate change after warnings of scientists have been largely ignored for more than 30 years. We wish her and the movement the endurance necessary to keep the pressure up!

\section{Material examined}

\section{Holotype (Fig. 4E)}

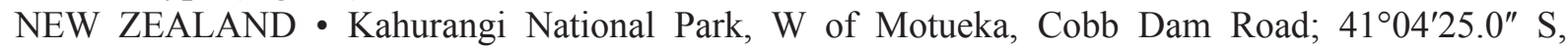
$172^{\circ} 45^{\prime} 18.5^{\prime \prime}$ E; 1 Mar. 2016; G. Verhaegen and M. Haase leg.; on leaves, stones, woody debris in trickle along road; NMNZ.M.330191.

Paratypes (Figs. 4F; 5D-E)

NEW ZEALAND • 21 specs; same collection data as for holotype; NMNZ.M.330192.

\section{Description}

SHELl (Figs 4E-F, 5D-E). Blunt-conical to pupiform, about 1.65 times as high as than wide, whitetranslucent with brown periostracum; protoconch almost smooth with fine pits comprising ca 0.75 whorl (Fig. 6D); entire shell with 3.5 to 4.25 whorls, teleoconch initially with fine longitudinal ridges, then without structure apart from growth lines; umbilicus narrow; aperture orthocline, slightly higher than wide.

OPERCULUM. Orange, paucispiral; nucleus submarginal, without peg.

EXTERNAL FEATURES (Figs 4E-F). Epidermis with irregular, large pigment blotches; eyes well developed and entirely pigmented; tentacles without particular ciliation.

MANTLE CAVITY $(\mathrm{n}=3)$. 10-12 ctenidial filaments; osphradium ovate-elongate, behind middle of gill.

Digestive system. Radula has formula R 5-6 1 5-6/3-4 3-4, L 5-6 1 6, M1 22-26, M2 31-32 (Fig. 8C); stomach without caecum; rectal loop pointing left in roof of mantle cavity, in males more distinct than in females. 
Female genitalia $(\mathrm{n}=2$; Fig. 12). Ovary small, simple sac starting $>1.5$ whorls below apex, comprising 0.25 whorl and not reaching stomach; renal oviduct first coiling $180^{\circ}$ clockwise, then $270^{\circ}$ counterclockwise; one distal, large receptaculum seminis lying against anterior area of bursa copulatrix; bursa copulatrix large, globular, extending behind much smaller albumen gland, bursal duct entering anteriorly; ovoviviparous, brooding at least three embryos in pallial oviduct, pallial oviduct as brood pouch with very short albumen gland and large capsule gland, the latter histologically uniform in CT scans.

Male genitalia $(n=4)$. Testis lobate sac, starting ca 0.75 whorl below apex, comprising up to 1 whorl, may reach stomach; vesicula seminalis coils along anterior half of testis; proximal vas deferens inserts close to middle of kidney-shaped prostate, distal vas deferens leaving anteriorly; penis long, slender, continuously tapering, pointed; distinct lobe on right side pointing forward (Fig. 11B).

\section{Remarks}

The sister relationship of $O p$. gretathunbergae sp. nov. to Op. ngatapuna was fairly well supported (Fig. 2). The average COI p-distance was 0.014 and there were eight type 1 characters in COI and three in 16S (Table 2). Morphologically, the new species is larger. Univariate tests comparing shell dimensions could not be conducted, though, because of the small sample size available for Op. ngatapuna. But the PCA (Fig. 3) and the data in Haase (2008) are clear regarding the size difference. Anatomically, only the

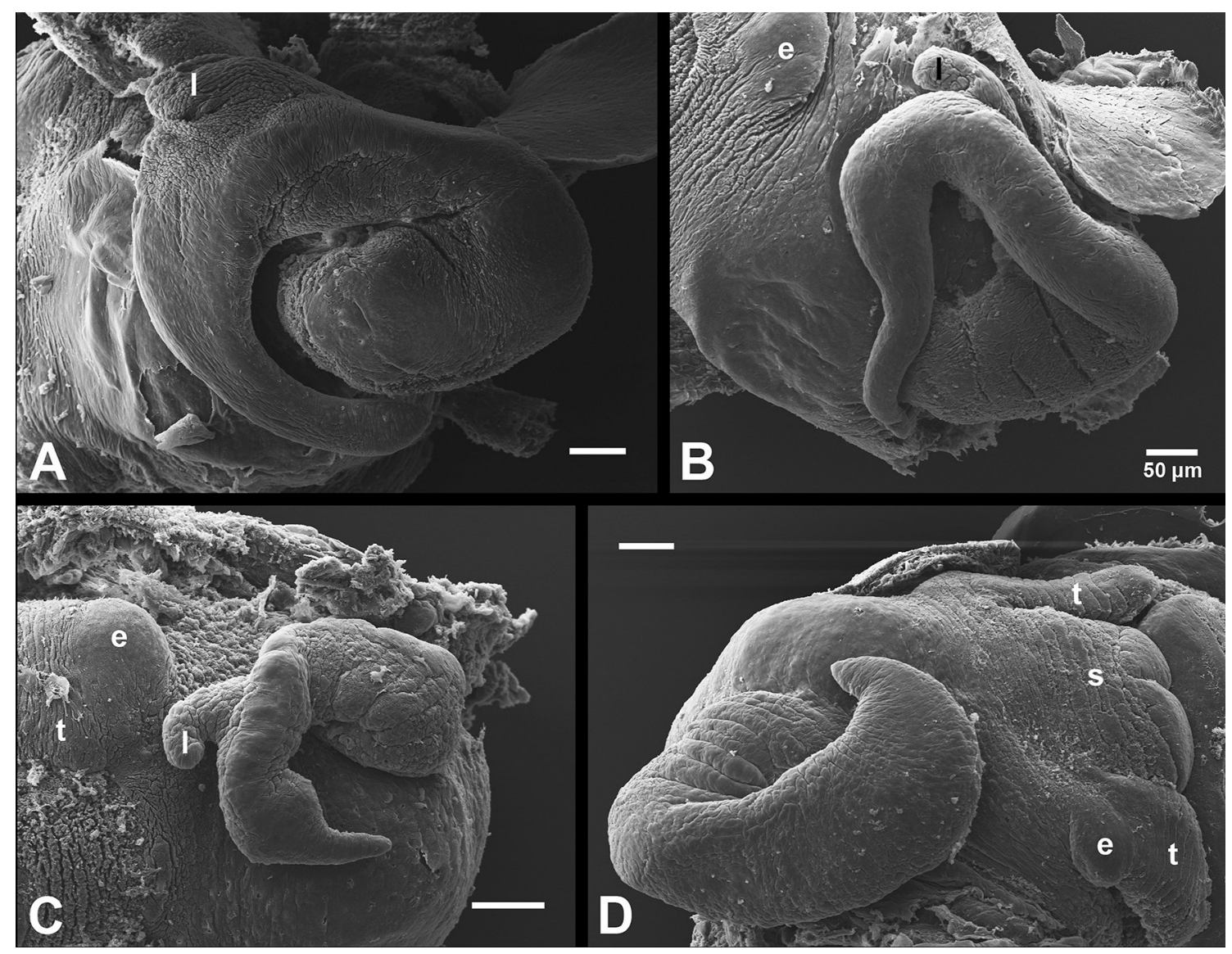

Fig. 11. Penis. SEM photographs. A. Opacuincola lisannea sp. nov. (from type locality). B. Op. gretathunbergae sp. nov. C. Op. mete kahurangi subsp. nov. D. Obtusopyrgus farri sp. nov. Abbreviations: $\mathrm{e}=$ eye $; \mathrm{l}=$ penial lobe $\mathrm{s}=$ snout; $\mathrm{t}=$ tentacle. 
male genitalia could be compared because this information is lacking for Op. ngatapuna (Haase 2008). The well-developed eyes indicate that the new species is a true crenobiont.

Opacuincola mete kahurangi subsp. nov. urn:1sid:zoobank.org:act:D05FF1E3-5A77-4C4F-AA94-C8E7356F36C7

Figs 4G-H, 5F-G, 6E, 11C, 13; Table 1

\section{Diagnosis}

The new subspecies differs from the nominate form in shell morphology. It is much larger and broadlyconical while the latter has a rather ovate shell. Both are identical in anatomy.

\section{Etymology}

Opacuincola mete kahurangi subsp. nov. is named after Kahurangi National Park, the second largest National Park in New Zealand in the northeast of the South Island, where the type locality is situated.

\section{Material examined}

\section{Holotype (Fig. 4G)}

NEW ZEALAND • Kahurangi National Park, NE of Karamea, Fenian Track, under bridge over Cavern Creek; 41 ${ }^{\circ} 12^{\prime} 02.5^{\prime \prime}$ S, $172^{\circ} 11^{\prime} 08.4^{\prime \prime}$ E; 5 Mar. 2016; G. Verhaegen and M. Haase leg.; on rough rocks in river; NMNZ.M.330193.

Paratypes (Figs 4H, 5F-G)

NEW ZEALAND • 21 specs; same collection data as for holotype; NMNZ.M.330194.

\section{Description}

Shell (Figs 4G-H, 5F-G). Broadly-conical to globular, only about 1.2 times as high as than wide, translucent with brown periostracum; protoconch almost smooth, comprising ca 1 whorl (Fig. 6E); entire shell with 3.125 to 4 whorls, teleoconch without structure apart from growth lines; umbilicus a wider slit; aperture large, wider than high, about half as high as total shell height and more than half as wide as total width, apertural lip slightly sinuated both ad- and abapically.

OPERCULUM. Orange, paucispiral; nucleus submarginal, without peg.

EXTERNAL FEATURES. Epidermis without pigment; eyes well developed and entirely pigmented; tentacles without particular ciliation.

MANTLE CAVITY $(\mathrm{n}=4) .9-12$ ctenidial filaments; osphradium ovate-elongate, behind middle of gill.

Digestive system. Radula has formula R 5-6 1 5-6/3-4 3-4, L 51 5-6, M1 23-28, M2 29-30; stomach without caecum; rectal loop pointing left in roof of mantle cavity, in males more distinct than in females.

Female genitalia ( $\mathrm{n}=3$; Fig. 13A). Ovary small, simple sac starting ca 1 whorl below apex, comprising 0.25 whorl and not reaching stomach; renal oviduct first coiling $180^{\circ}$ clockwise, then $270^{\circ}$ counterclockwise; one distal, large receptaculum seminis lying against anterior area of bursa copulatrix; bursa copulatrix large, globular, largely behind short albumen gland, fairly long bursal duct entering anteriorly; ovoviviparous, brooding at least four embryos in pallial oviduct, pallial oviduct as brood pouch with very short albumen gland and large capsule gland, the latter histologically uniform in CT scans.

Male genitalia ( $\mathrm{n}=3$; Fig. 13B). Testis lobate sac, starting ca 1 whorl below apex, comprising up to 0.75 whorl, not reaching stomach; vesicula seminalis coils along anterior third of testis; proximal vas 
deferens inserts close to middle of kidney-shaped prostate, distal vas deferens leaving anteriorly; penis not very massive, with subterminal swelling and short terminal filament, fairly long muscular lobe on right side eventually bent forward (Figs 11C, 13B).

\section{Remarks}

In shell morphology, Op. m. kahurangi ssp. nov. is clearly distinct form the nominate form. Univariate tests could not be conducted because of the small sample size available for the latter. However, the

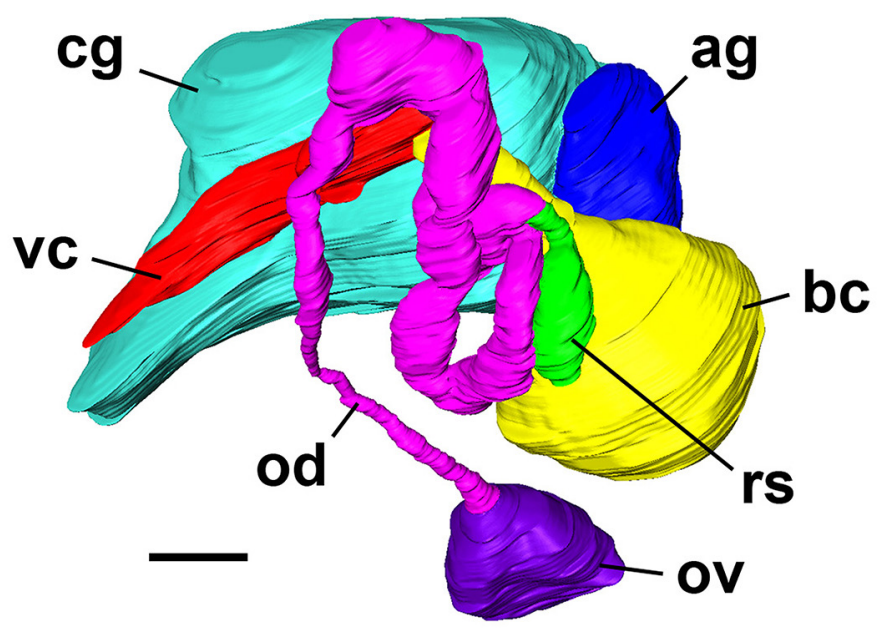

Fig. 12. Female genitalia of Opacuincola gretathunbergae sp. nov. $\mu \mathrm{CT}$ scans. Abbreviations: ag $=$ albumen gland; $\mathrm{bc}=$ bursa copulatrix; $\mathrm{cg}=$ capsule gland; od = oviduct; ov = ovary; $\mathrm{rs}=$ receptaculum seminis; $\mathrm{vc}=$ ventral channel. Scale bar $=50 \mu \mathrm{m}$.

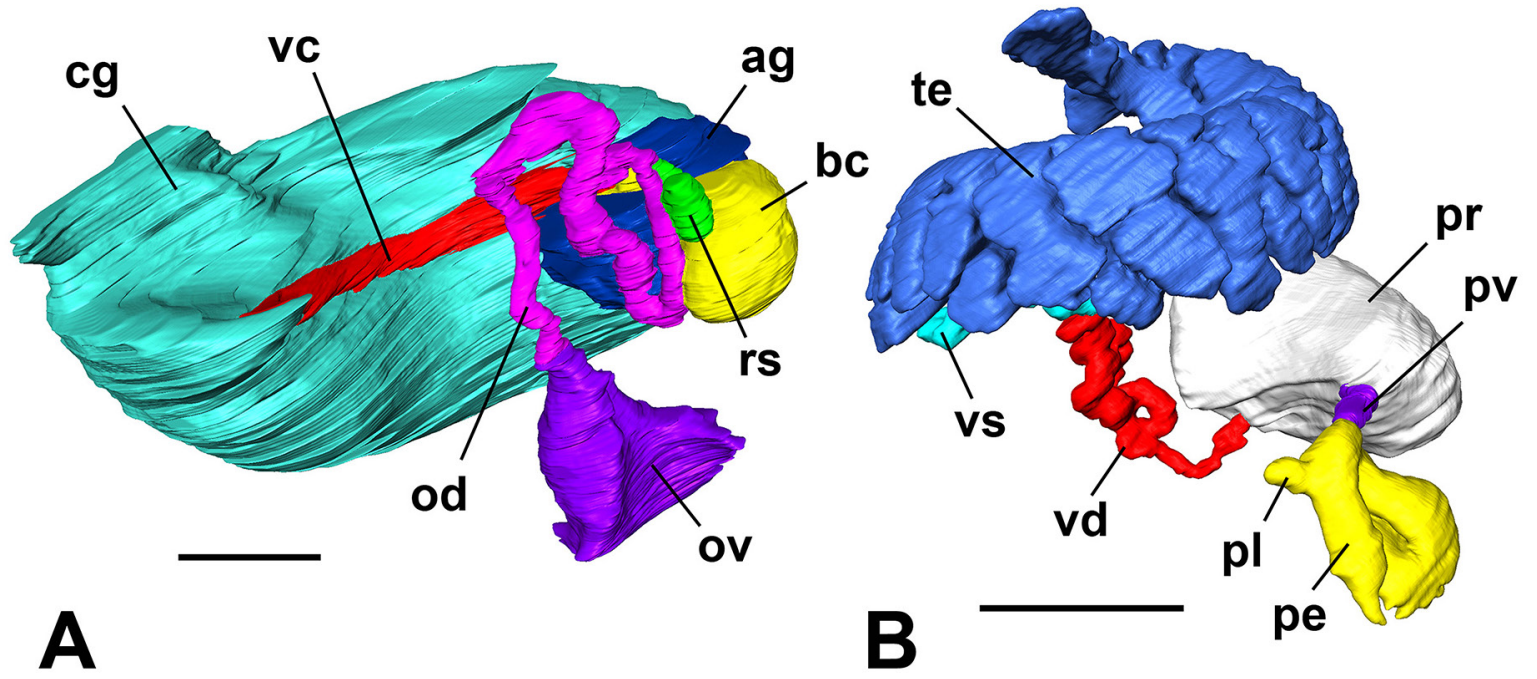

Fig. 13. Genitalia of Opacuincola m. kahurangi subsp. nov. $\mu$ CT scans. A. + . B. $\widehat{\jmath}$. Abbreviations: ag = albumen gland; $\mathrm{bc}=$ bursa copulatrix; $\mathrm{cg}=$ capsule gland; od = oviduct; ov = ovary; $\mathrm{pe}=$ penis; $\mathrm{pl}=$ penial lobe; $\mathrm{pr}=$ prostate; $\mathrm{pv}=$ pallial vas deferens; $\mathrm{rs}=$ receptaculum seminis; te $=$ testis; $\mathrm{vc}=$ ventral channel; $v d=$ vas deferens; vs $=$ vesicula seminalis. Scale bars $=100 \mu \mathrm{m}$. 
PCA is unambiguous (Fig. 3). Anatomically, they are practically identical and in the mitochondrial phylogeny not separable (Fig. 2). Both are known each from a single locality, which are ca $90 \mathrm{~km}$ apart (as the crow flies). Because of the high overall similarity, we distinguish these forms only as subspecies, although they can easily be told apart by their shells. However, we do not know if there exist connecting populations between both sites mediating gene flow in a stepping stone-like fashion. Considering similar cases among Tateidae form New Zealand and other places, we might be witnessing species in statu nascendi or already be dealing with genetically incompatible but mitochondrially undifferentiated, young species (e.g., Haase 2005, 2008; Zielske \& Haase 2014a, 2014b). Nuclear genetic data might be more informative in this ambiguous situation. The new subspecies represents one of the rare cases where a small tateid is not restricted to springs or small streams. Due to the unresolved situation in the mitochondrial phylogeny (Fig. 2), it is not reasonable to list diagnostic alignment positions.

Genus Obtusopyrgus Haase, 2008

Obtusopyrgus farri sp. nov. urn:1sid:zoobank.org:act:2D7008F8-BB41-448D-94AF-969925CECDAB

Figs 4I-J, 5H-I, 6F, 8D, 11D, 14; Tables 1-2

\section{Diagnosis}

In the new species, the central tooth of the radula has more cusps on the edge and less on the basis than in the only other known representative of the genus, Ob. alpinus. The bursa copulatrix is smaller and more elongate compared to the larger, more globular one in the latter. As a consequence, the seminal receptacle reaches far behind the bursa in Ob. farri sp. nov., whereas in Ob. alpinus it lies entirely against the bursa. These species differ at five diagnostic alignment positions of type 1 .

\section{Etymology}

Obtusopyrgus farri sp. nov. is named after Gareth Farr, acclaimed New Zealand percussionist and composer integrating non-European music styles including Maori music into Western classical music resulting in the most fascinating and colorful synthesis of different musical expressions. His alter ego, the drag queen Lilith LaCroix, is also colorful.

\section{Material examined}

Holotype (Fig. 4I)

NEW ZEALAND • Nelson Lakes National Park, Lake Rotoiti, small stream crossing Lakeside Track close to lake shore; 41 ${ }^{\circ} 49^{\prime} 30.7^{\prime \prime}$ S, 172 ${ }^{\circ} 49^{\prime} 50.1^{\prime \prime}$ E; 13 Mar. 2016; G. Verhaegen and M. Haase leg.; on leaves, stones, woody debris in small stream crossing track; NMNZ.M.330195.

Paratypes (Figs 4J; 5H-I)

NEW ZEALAND • 21 specs; same collection data as for holotype; NMNZ.M.330196.

\section{Description}

SHell (Figs 4I-J, 5H-I). Blunt-ovate to pupiform, about 1.7 times as high as than wide, light brown, translucent with brown periostracum; protoconch almost smooth, comprising up to 1 whorl (Fig. 6F); entire shell with 3.625 to 4.25 whorls, teleoconch initially with very fine longitudinal ridges, then without structure apart from growth lines; umbilicus narrow; aperture orthocline, as high as wide.

Operculum. Yellow to light orange, paucispiral; nucleus submarginal, without peg.

EXTERNAL FEATURES (Figs 4I-J). Epidermis with irregular, large pigment blotches; eyes well developed and entirely pigmented; tentacles without particular ciliation. 
Mantle Cavity $(\mathrm{n}=4)$. 8-11 ctenidial filaments; osphradium ovate-elongate, behind middle of gill.

Digestive system. Radula has formula R 5 1 5/2-3 2-3, L 5-7 1 5-7, M1 23-28, M2 25-28 (Fig. 8D); stomach without caecum; rectal loop pointing left in roof of mantle cavity, in males more distinct than in females.

Female genitalia ( $\mathrm{n}=4$; Fig. 14). Ovary lobate sac starting $>1.5$ whorls below apex, comprising ca 0.3 whorl and not reaching stomach; renal oviduct first coiling $180^{\circ}$ clockwise, then $270^{\circ}$ counterclockwise; one distal, large receptaculum seminis reaching far behind bursa copulatrix; bursa copulatrix an elongate sac lying behind albumen gland, bursal duct entering anteriorly; ovoviviparous, brooding at least three embryos in pallial oviduct, pallial oviduct as brood pouch, albumen gland has about third of length of capsule gland, the latter histologically uniform in CT scans.

Male genitalia $(\mathrm{n}=1)$. Testis lobate sac, starting ca 1 whorl below apex, comprising up to 1 whorl, reaching stomach; vesicula seminalis coils along anterior half of testis; proximal vas deferens inserts close to middle of kidney-shaped prostate, distal vas deferens leaving anteriorly; penis massive, broad, short, pointed tip, without appendages (Fig. 11D).

\section{Remarks}

The new species is slightly larger than Ob. alpinus (shell height: Mann-Whitney U-test: $\mathrm{z}=2.869, \mathrm{p}=$ 0.004), but in terms of shape, they cannot be distinguished (shell height/shell width: Mann-Whitney U-test: $\mathrm{z}=0.764, \mathrm{p}=0.445$ ). The genetic and phylogenetic distinction of both species of Obtusopyrgus was only based on $16 \mathrm{~S}$ as sequencing of COI failed (Fig. 2). There were five diagnostic characters (Table 2). The well-developed eyes indicate that $O b$. farri sp. nov. inhabits epigean waters.

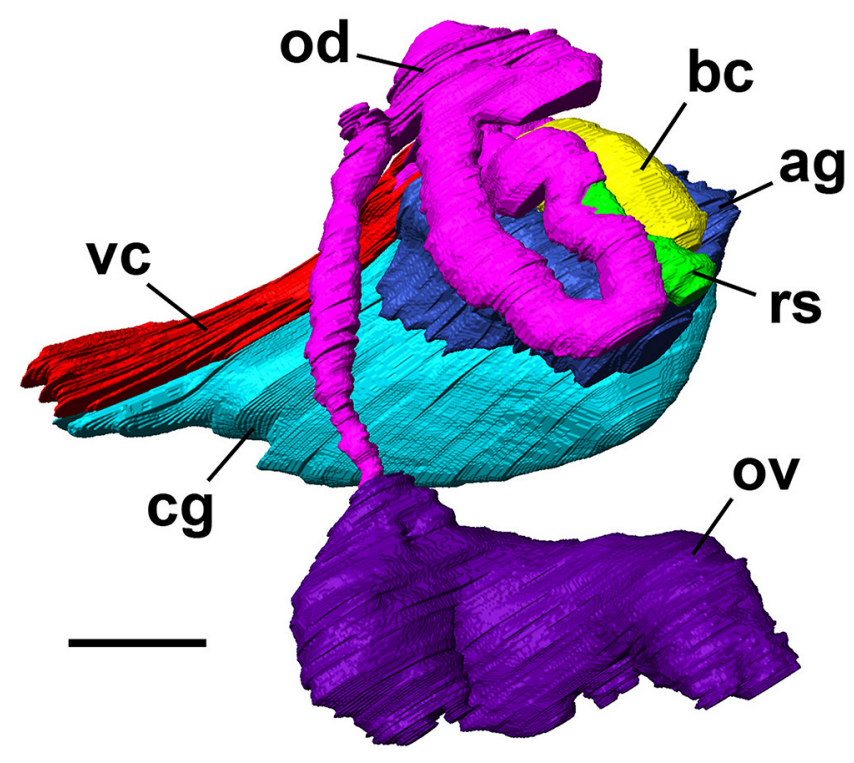

Fig. 14. Female genitalia of Obtusopyrgus farri sp. nov. $\mu \mathrm{CT}$ scans. Abbreviations: ag = albumen gland; $\mathrm{bc}=$ bursa copulatrix; $\mathrm{cg}=$ capsule gland; od = oviduct; ov = ovary; $\mathrm{rs}=$ receptaculum seminis; $\mathrm{vc}=$ ventral channel. Scale bar $=100 \mu \mathrm{m}$. 


\section{Discussion}

Due to the high number and proportion of endemic species, New Zealand is regarded as one of 36 biodiversity hotspots (Myers et al. 2000; Mittermeier et al. 2004; see also Kier et al. 2009; Veron et al. 2019) and the number of species discoveries keeps growing. A quick search in the Web of Science with the search terms "New Zealand species" in "Topic" and only the three selected taxonomic journals European Journal of Taxonomy, ZooKeys or Zootaxa in "Publication Name" revealed a total of 143 new species published only in the years 2018 and 2019. With the four new species introduced here, the number of tateid gastropod species, all of them endemic to New Zealand (including P. antipodarum being invasive in many parts of the world, see Introduction), increased to 68. Although we do not know the entire ranges of the new species, they appear to fit into the pattern of narrow-range endemism typical for the New Zealand representatives of the family (see Introduction). Their discovery is remarkable for two reasons: 1) our fieldwork did not target species other than $P$. antipodarum (see Verhaegen et al. 2018b); and 2) we spent hardly two weeks in 2016 in the north of the South Island. Considering this and the fact that all five localities were easily accessible along tracks and roads and only in the case of $O p$. $m$. kahurangi subsp. nov. in more than two hours walking distance from the car park, we can predict that still many more species await discovery.

To our best knowledge, this is the first paper applying $\mu \mathrm{CT}$ scanning in truncatelloidean gastropods to reconstruct their genital system. In comparison to dissections, there are some pros and cons to this approach. In contrast to dissections, the original organ situs remains intact and apart from the fact that the shell had to be dissolved in order to optimize the contrast among the tissues, the specimens do not have to be destroyed so that they can be preserved and included in the type series. On the downside, the resolution of thin structures like the vas deferens or the oviduct has often been wanting (e.g., Fig. 9) and although one of us (MH) has a lot of experience with histological serial sectioning and their reconstruction (e.g., Haase \& Bouchet 1998), these structures occasionally could not be detected. Similarly, delicate details could not be resolved in particular in cases where an organ or parts of an organ bend onto itself such as the hook-shape of the penial lobe in Op. lisannea sp. nov. (Figs 10B, 11) or the entire penis of $C$. jami sp. nov. All of this might be possible in dissections depending on the skills of the researcher and the size of the snails. It has to be stated though, that our material has been fixed only in ethanol. It is thus very likely that the drawbacks of $\mu \mathrm{CT}$-scanning can be overcome by fixation in e.g., formalin so that also very small species can be studied in full anatomical detail.

Incorporating DNA character data into taxonomic diagnoses has already been suggested about 20 years ago. However, as of November 2015 Renner (2016) has found only 98 descriptions explicitly including DNA data, although morphologically cryptic taxa can usually only be identified based on other genetic data. One reason for the seeming reluctance to use DNA characters also in diagnoses was possibly the lack of suitable tools for their identification (Kühn \& Haase 2020). With the correction of this deficiency (Hütter et al. 2020; Kühn \& Haase 2020) cryptic taxa such as our tateid gastropods will hopefully be formally described at an increasing rate and not stay in taxonomic crypsis (SchlickSteiner et al. 2007). In contrast to Renner (2016), we do not advocate the replacement of morphological descriptions and diagnoses by DNA-based diagnoses, as we still usually deal with phenotypes and therefore cannot dispense with morphological data in taxonomy. Characters of all qualities should be seen as complementary in the sense of what has been dubbed integrative taxonomy (Dayrat 2005; Padial et al. 2010; Schlick-Steiner et al. 2010).

Our descriptions were based on relatively few individuals and some of the sequenced specimens even shared identical haplotypes. One might therefore question how meaningful DNA-based diagnoses are when data are limited. This touches on the general question of how to deal with rarity in taxonomy. Do we need a minimum number of specimens per population and populations per species to warrant taxonomic recognition? Considering that a large proportion of all species across all taxa are rare (Lim 
et al. 2012), often because their ranges are very restricted or their habitats difficult to access as in many tateids, one can only conclude with these authors that rarity is an inherent property of biodiversity and the neglect of rare taxa would impact severely on conservation biology, ecology and evolutionary biology. In taxonomy, this means that the variation of characters, regardless if morphological or molecular, may be limited at the time of description. A diagnosis may have to be extended or amended once more specimens become available. But again, this holds for morphological characters as well as for molecular characters. Thus, a molecular character identified as diagnostic and fixed for one state (A, C, G, T, or gap), a type 1 character according to Kühn \& Haase (2020), might erode to a type 2 or type 3 character or eventually no longer be diagnostic, adding new information. This is analogous to a case where two species initially considered to differ in size no longer do so after new populations have been discovered.

Diagnoses are relative. With that respect we found it particularly interesting that in Op. gretathunbergae sp. nov., well defined from its sister species Op. ngatapuna at eight positions in COI and three in $16 \mathrm{~S}$ rRNA, only a single diagnostic position or type 1 remained in the comparison across all congeners (Table 2). This indicates a high frequency of homoplastic mutations in COI. Similar observations were made among tateids from New Caledonia (Zielske \& Haase 2015).

\section{Acknowledgments}

We thank Silke Fregin for assisting with the DNA lab work. Marie Hörnig and Stefan Bock are acknowledged for running the $\mu \mathrm{CT}$. Stefan Bock also did the electron microscope scans. Tim Dederich and Peter Michalik introduced us to AMIRA and Gabriele Uhl gave access to the Zeiss microscope. These persons are all colleagues at the University of Greifswald. We are grateful to Bruce Marshall (Te Papa Tongarewa, Wellington, New Zealand) for providing specimens of known species for comparisons. Winston F. Ponder and an anonymous referee provided invaluable comments improving the first version of the manuscript. Fieldwork was conducted under the Research and Collection Authorisation 48020RES issued by the Department of Conservation. Our research in the frame of the Research Training Group RESPONSE (RTG 2010) has been funded by the Deutsche Forschungsgemeinschaft.

\section{References}

Alonso Á. \& Castro-Díez P. 2012. The exotic aquatic mud snail Potamopyrgus antipodarum (Hydrobiidae, Mollusca): state of the art of a worldwide invasion. Aquatic Sciences 74: 375-383. https://doi.org/10.1007/s00027-012-0254-7

Dayrat B. 2005. Toward integrative taxonomy. Biological Journal of the Linnean Society 85: 407-415. https://doi.org/10.1111/j.1095-8312.2005.00503.x

Folmer O., Black M., Hoeh W., Lutz R. \& Vrijenhoek R. 1994. DNA primers for amplification of mitochondrial cytochrome c oxidase subunit I from diverse metazoan invertebrates. Molecular Marine Biology and Biotechnology 3: 294-299.

Haase M. 2005. Rapid and convergentevolution of parental care in hydrobiid gastropods from NewZealand. Journal of Evolutionary Biology 18: 1076-1086. https://doi.org/10.1111/j.1420-9101.2005.00894.x

Haase M. 2008. The radiation of hydrobiid gastropods in New Zealand: a revision including the description of new species based on morphology and mtDNA sequence information. Systematics and Biodiversity 6: 99-159. https://doi.org/10.1017/S1477200007002630

Haase M. \& Bouchet P. 1998. Radiation of crenobiontic gastropods on an ancient continental island: the Hemistomia-clade in New Caledonia (Gastropoda: Hydrobiidae). Hydrobiologia 367: 43-129.

https://doi.org/10.1023/A:1003219931171 
Haase M., Marshall B.A. \& Hogg I. 2007a. Disentangling causes of disjunction on the South Island of New Zealand: the Alpine fault hypothesis of vicariance revisited. Biological Journal of the Linnean Society 91: 361-374. https://doi.org/10.1111/j.1095-8312.2007.00801.x

Haase M., Wilke T. \& Mildner P. 2007b. Identifying species of Bythinella (Caenogastropoda: Rissooidea): a plea for an integrative approach. Zootaxa 1563 (1): 1-16. https://doi.org/10.11646/zootaxa.1563.1.1

Hall T.A. 1999. BioEdit: a user-friendly biological sequence alignment editor and analysis program for Windows 95/98/NT. Nucleic Acids Symposium Series 41: 95-98.

Hammer Ø., Harper D.A.T. \& Ryan P.D. 2001. PAST: Palaeontological Statistics software package for education and data analysis. Palaeontologia Electronica. 4: 4.

Hütter T., Ganser M.H., Kocher M., Halkic M., Agatha S. \& Augsten N. 2020. DeSignate: detecting signature characters in gene sequence alignments for taxon diagnoses. BMC Bioinformatics 21: 151. https://doi.org/10.1186/s12859-020-3498-6

Katoh K., Rozewicki J. \& Yamada K.D. 2019. MAFFT online service: multiple sequence alignment, interactive sequence choice and visualization. Briefings in Bioinformatics 20: 1160-1166.

https://doi.org/10.1093/bib/bbx108

Kerney M.P. \& Cameron R.A.D. 1979. Field Guide to the Land Snails of Britain and North-West Europe. Collins, London.

Kier G., Kreft H., Lee T.M., Jetz W., Ibisch P.L., Nowicki C., Mutke J. \& Barthlott W. 2009. A global assessment of endemism and species richness across island and mainland regions. Proceedings of the National Academy of Sciences 106: 9322-9327. https://doi.org/10.1073/pnas.0810306106

Kühn A.L. \& Haase M. 2020. QUIDDICH - QUick IDentification of DIagnostic CHaracters. Journal of Zoological Systematics and Evolutionary Research 58: 22-26. https://doi.org/10.1111/jzs.12347

Kumar S., Stecher G., Li M., Knyaz C. \& Tamura K. 2018. MEGA X: Molecular Evolutionary Genetics Analysis across computing platforms. Molecular Biology and Evolution 35: 1547-1549.

https://doi.org/10.1093/molbev/msy096

Lanfear R., Frandsen P.B., Wright A.M., Senfeld T. \& Calcott B. 2017. Partitionfinder 2: New methods for selecting partitioned models of evolution for molecular and morphological phylogenetic analyses. Molecular Biology and Evolution 34 (3): 772-773. https://doi.org/10.1093/molbev/msw260

Lim G.S., Balke M. \& Meier R. 2012. Determining species boundaries in a world full of rarity: singletons, species delimitation methods. Systematic Biology 61: 165-169. https://doi.org/10.1093/sysbio/syr030

Mittermeier R.A., Robles Gil P., Hoffmann M., Pilgrim J., Brooks T., Goettsch Mittermeier C., Lamoureux J. \& da Fonseca G.A.B. 2004. Hotspots Revisited. CEMEX, Mexico City.

Myers N., Mittermeier R.A., Goettsch Mittermeier C., da Fonseca G.A.B. \& Kent J. 2000. Biodiversity hotspots for conservation priorities. Nature 403: 853-858. https://doi.org/10.1038/35002501

Nation J.L. 1983. A new method using hexamethyldisilazane for preparation of soft insect tissues for scanning electron microscopy. Stain Technology 58: 347-351. https://doi.org/10.3109/10520298309066811

Padial J.M., Miralles A., De la Riva I. \& Vences M. 2010. The integrative future of taxonomy. Frontiers in Zoology 7: 16. https://doi.org/10.1186/1742-9994-7-16

Palumbi S.R., Martin A., Romano S., McMillan W.O., Stice L. \& Grabowski G. 1991. The Simple Fool's Guide to PCR, version 2.0. University of Hawaii, Honolulu.

Ponder W.F. 1982. Hydrobiidae of Lord Howe Island (Mollusca: Gastropoda: Prosobranchia). Australian Journal of Marine and Freshwater Research 33: 89-159. https://doi.org/10.1071/MF9820089 
Ponder W.F. 1988. Potamopyrgus antipodarum: a molluscan colonizer of Europe and Australia. Journal of Molluscan Studies 54: 271-285. https://doi.org/10.1093/mollus/54.3.271

Ponder W.F. 2019. Tateidae. In: Lydeard C. \& Cummings K.S. (eds) Freshwater Gastropods of the World: a Distribution Atlas: 134-138. Johns Hopkins University Press, Baltimore.

R Core Team 2020. R: A language and environment for statistical computing. R Foundation for Statistical Computing, Vienna, Austria. https://www.R-project.org

Renner S. 2016. A return to Linnaeus's focus on diagnosis, not description: The use of DNA characters in the formal naming of species. Systematic Biology 65: 1085-1095. https://doi.org/10.1093/sysbio/syw032

Ronquist F., Teslenko M., van der Mark P., Ayres D.L., Darling A., Höhna S., Larget B., Liu L., Suchard M.A. \& Huelsenbeck J.P. 2012. MrBayes 3.2: Efficient Bayesian phylogenetic inference and model choice across a large model space. Systematic Biology 61: 539-542.

Schilthuizen M. \& Haase M. 2010. Disentangling true shape differences and experimenter bias: are dextral and sinistral snail shells exact mirror images? Journal of Zoology 282: 191-200.

https://doi.org/10.1111/j.1469-7998.2010.00729.x

Schlick-Steiner B.C., Seifert B., Stauffer C., Christian E., Crozier R.H. \& Steiner F.M. 2007. Without morphology, cryptic species stay in taxonomic crypsis following discovery. Trends in Ecology \& Evolution 22 (8): 391-392. https://doi.org/10.1016/j.tree.2007.05.004

Schlick-Steiner B.C., Steiner F.M., Seifert B., Stauffer C., Christian E. \& Crozier R.H. 2010. Integrative taxonomy: A multisource approach to exploring biodiversity. Annual Review of Entomology 55: 421438. https://doi.org/10.1146/annurev-ento-112408-085432

Swofford D.L. 2002. PAUP*. Phylogenetic Analysis Using Parsimony (*and other methods). Version 4. Sinauer Associates, Sunderland, Massachusetts.

Verhaegen G., McElroy K.E., Bankers L., Neiman M. \& Haase M. 2018a. Adaptive phenotypic plasticity in a clonal invader. Ecology and Evolution 8: 4465-4483. https://doi.org/10.1002/ece3.4009

Verhaegen G., Neiman M. \& Haase M. 2018b. Ecomorphology of a generalist freshwater gastropod: complex relations of shell morphology, habitat, and fecundity. Organisms, Diversity and Evolution 18: 425-441. https://doi.org/10.1007/s13127-018-0377-3

Veron S., Haevermans T., Govaerts R., Mouchet M. \& Pellens R. 2019. Distribution and relative age of endemism across islands worldwide. Scientific Reports 9: 11693.

https://doi.org/10.1038/s41598-019-47951-6

Zielske S. \& Haase M. 2014a. When snails inform about geology: Pliocene emergence of islands of Vanuatu indicated by a radiation of truncatelloidean freshwater gastropods (Caenogastropoda: Tateidae). Journal of Zoological Systematics and Evolutionary Research 52: 217-236. https://doi.org/10.1111/jzs.12053

Zielske S. \& Haase M. 2014b. New insights into tateid gastropods and their radiation on Fiji based on anatomical and molecular methods (Caenogastropoda: Truncatelloidea). Zoological Journal of the Linnean Society 172 (1): 71-102. https://doi.org/10.1111/zoj.12153

Zielske S. \& Haase M. 2015. Molecular phylogeny and a modified approach of character-based barcoding refining the taxonomy of New Caledonian freshwater gastropods (Caenogastropoda, Truncatelloidea, Tateidae). Molecular Phylogenetics and Evolution 89: 171-181.

https://doi.org/10.1016/j.ympev.2015.04.020

Zielske S., Glaubrecht M. \& Haase M. 2011. Origin and radiation of rissooidean gastropods (Caenogastropoda) in ancient lakes of Sulawesi. Zoologica Scripta 40: 221-237.

https://doi.org/10.1111/j.1463-6409.2010.00469.x 
Zielske S., Ponder W.F. \& Haase M. 2017. The enigmatic pattern of long-distance dispersal of minute freshwater gastropods (Caenogastropoda, Truncatelloidea, Tateidae) across the South Pacific. Journal of Biogeography 44: 195-206. https://doi.org/10.1111/jbi.12800

Zwickl D.J. 2006. Genetic algorithm approaches for the phylogenetic analysis of large biological sequence datasets under the maximum likelihood criterion. PhD thesis. University of Texas, Austin.

Manuscript received: 23 July 2020

Manuscript accepted: 14 October 2020

Published on: 18 January 2021

Topic editor: Rudy Jocqué

Section editor: Thierry Backeljau

Desk editor: Marianne Salaün

Printed versions of all papers are also deposited in the libraries of the institutes that are members of the EJT consortium: Muséum national d'histoire naturelle, Paris, France; Botanic Garden Meise, Belgium; Royal Museum for Central Africa, Tervuren, Belgium; Royal Belgian Institute of Natural Sciences, Brussels, Belgium; Natural History Museum of Denmark, Copenhagen, Denmark; Naturalis Biodiversity Center, Leiden, the Netherlands; Museo Nacional de Ciencias Naturales-CSIC, Madrid, Spain; Real Jardín Botánico de Madrid CSIC, Spain; Zoological Research Museum Alexander Koenig, Bonn, Germany; National Museum, Prague, Czech Republic.

Supplementary File 1. Alignment of COI. https://doi.org/10.5852/ejt.2021.731.1205.3415

Supplementary File 2. Alignment of 16S rRNA. https://doi.org/10.5852/ejt.2021.731.1205.3417 